THE EVALUATION OF THE X-RAY FLUORESCENCE (XRF) TECHNIQUE FOR PROCESS MONITORING OF VITREOUS SLAG FROM THERMAL WASTE TREATMENT SYSTEMS: A COMPARATIVE STUDY OF THE ANALYSIS OF PLASMA HEARTH SLAG FOR CE, FE AND CR BY XRF AND INDUCTIVELY COUPLED PLASMA SPECTROMETRIES

by

M. A. H. Sutton, P. J. Crane, D. G. Cummings and K. P. Carney

Argonne National Laboratory-West

Engineering Division

P.O. Box 2528

Idaho Falls, ID 83403

NON-APPLIED TECHNOLOGY

DISTRIBUTION OF THIS DOCUMENT IS UNLIMITED 35 
Argonne National Laboratory, with facilities in the states of Illinois and Idaho, is owned by the Linited States govemment, and operated by The University of Chicago under the provisions of a contract with the Department of Energy.

\section{DISCLAIMER}

This report was prepared as an account of work sponsored by an agency of the United States Government. Neither the United States Government nor any agency thereof, nor any of their employees, makes any warranty, express or implied, or assumes any legal liability or responsibility for the accuracy, completeness, or usefulness of any information, apparanus, product, or process disclosed, or represents that its use would not infringe privately owned rights. Reference herein to any specific commercial product, process, or service by trade name, trademark, manufacturer, or otherwise, does not necessarily constitute or imply its endorsement, recommendation, or favoring by the United States Government or any agency thereof. The views and opinions of authors expressed herein do not necessarily state or reflect those of the United States Government or any agency thereof.

Reproduced from the best available copy.

Available to DOE and DOE contractors from the Office of Scientific and Technical Information

P.O. Box 62

Oak Ridge. TN 37831

Prices available from (615) 576-8401

Available to the public from the

National Technical Information Service

U.S. Department of Commerce

5285 Por Royal Road

Springfield, VA 22161 


\section{DISCLAIMER}

Portions of this document may be illegible in electronic image products. Images are produced from the best available original document. 
ABSTRACT $\ldots \ldots \ldots \ldots \ldots \ldots \ldots \ldots \ldots \ldots \ldots \ldots \ldots \ldots \ldots \ldots$ vii

I. INTRODUCTION $\ldots \ldots \ldots \ldots \ldots \ldots \ldots \ldots \ldots \ldots \ldots$

A. Process Monitoring Requirements $\ldots \ldots \ldots \ldots \ldots \ldots \ldots \ldots \ldots$

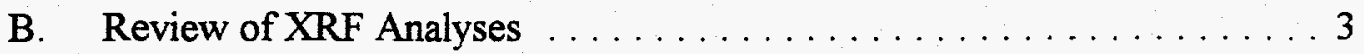

C. Review of XRF On-Line Monitoring Capabilities $\ldots \ldots \ldots \ldots \ldots 4$

D. Review of XRF Sample Preparation Procedures . . . . . . . . . 5

E. Review of Chemical Digestion Procedures for ICP-AES . . . . . . . 6

II. EXPERIMENTAL $\ldots \ldots \ldots \ldots \ldots \ldots \ldots \ldots \ldots \ldots$

A. Chemical Reagents $\ldots \ldots \ldots \ldots \ldots \ldots \ldots \ldots \ldots \ldots$

B. XRF Standard and Sample Preparation $\ldots \ldots \ldots \ldots \ldots \ldots \ldots \ldots$

C. ICP-AES Sample and Standards Preparation $\ldots \ldots \ldots \ldots \ldots \ldots 9$

D. Flow Injection--Inductively Coupled Plasma Spectrometer ........ 9

E. XRF Operating Parameters . . . . . . . . . . . . . . . . 13

III. RESULTS AND DISCUSSION $\ldots \ldots \ldots \ldots \ldots \ldots \ldots \ldots \ldots$

A. XRF Spectrometer Resolution $\ldots \ldots \ldots \ldots \ldots \ldots \ldots \ldots \ldots \ldots$

B. XRF Limits of Detection of Trace Elements in Glass . . . . . . . . 17

C. Chemical Analysis Plasma Hearth Slag by ICP-AES . . . . . . . 17

D. Determination of $\mathrm{Ce}, \mathrm{Fe}$ and $\mathrm{Cr}$ in Plasma Hearth Slag by XRF Spectrometry ......................... 22

E. XRF Analysis of Synthetic Standards for Cerium, Chromium, Nickel, Lead and Cadmium . . . . . . . . . . . . . . . . . . . . . . 26

F. Determination of $\mathrm{Ce}$ and $\mathrm{Cr}$ in PHP Slag by XRF Spectrometry . . . 31

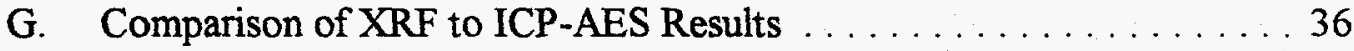

H. Evaluation of the Matrix Matching Routine for XRF Analyses of PHP Slag . . . . . . . . . . . . . . . . . . . 36

I. Core Analysis by ICP-AES and XRF for Ce Using Matrix Matching Routine ..........................42 42

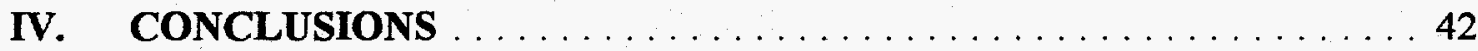

V. FUTURE WORK $\ldots \ldots \ldots \ldots \ldots \ldots \ldots \ldots \ldots \ldots \ldots$

ACKNOWLEDGMENTS $\ldots \ldots \ldots \ldots \ldots \ldots \ldots \ldots \ldots 44$

VI. APPENDIX. X-RAY SPECTROMETER TECHNICAL SPECIFICATIONS 


\section{LIST OF FIGURES}

Page

1. Method of Standard Additions for $\mathrm{Ce}$ in $\mathrm{LiBO}_{2}$ Solutions $\ldots \ldots \ldots \ldots \ldots 12$

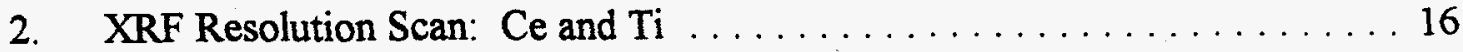

3. Ce XRF Composite Calibration Curve .................. 23

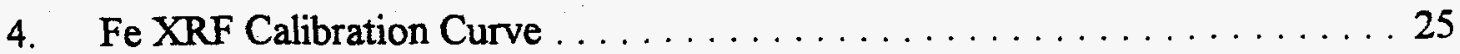

5. $\mathrm{Pb}$ XRF Calibration Curve . . . . . . . . . . . . . . . . . . . . 27

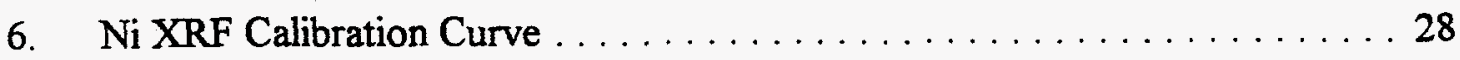

7. Cr XRF Calibration Curve . . . . . . . . . . . . . . . . . . . . . 29

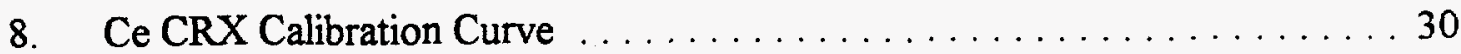




\section{LIST OF TABLES}

Page

1. Plasma Operating Parameters $\ldots \ldots \ldots \ldots \ldots \ldots \ldots \ldots \ldots \ldots$

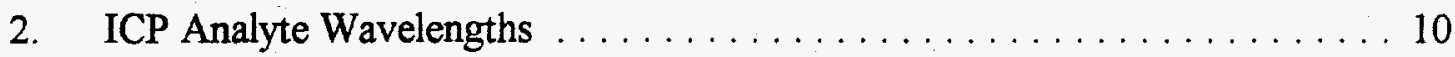

3. ICP Spectrometer Operating Parameters $\ldots \ldots \ldots \ldots \ldots \ldots \ldots \ldots 11$

4. XRF Spectrometer Operating Parameters $\ldots \ldots \ldots \ldots \ldots \ldots \ldots \ldots$

5. Effect of Interferants on XRF Analyte Signals $\ldots \ldots \ldots \ldots \ldots \ldots \ldots$

6. Estimated XRF Limits of Detection ...................... 17

7. FIA-ICP-AES Slag Analyses: M2S04 (Elemental Weight \%) . . . . . . . 19

8. FIA-ICP-AES Slag Analyses: M2S02 (Elemental Weight \%) . . . . . . . 19

9. FIA-ICP-AES Slag Analyses: M6S07 (Elemental Weight \%) . . . . . . 20

10. FIA-ICP-AES Slag Analyses: M4S05 (Elemental Weight \%) . . . . . . 20

11. XRF Standard Composition (Elemental Weight \%) ............ 21

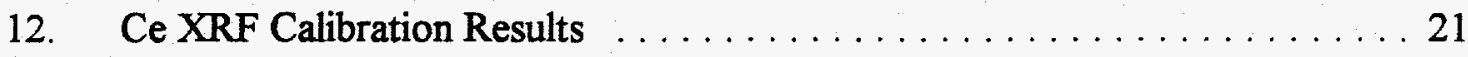

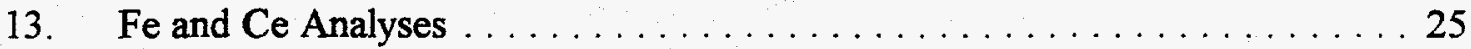

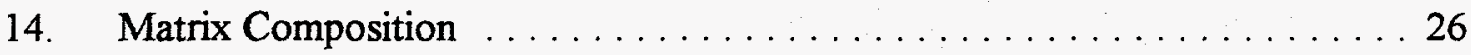

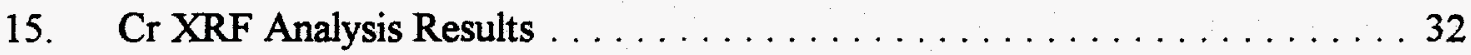

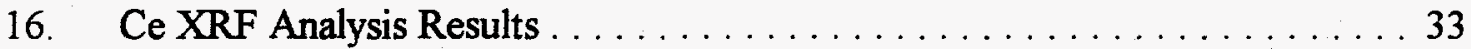

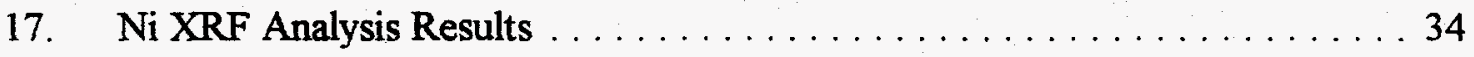

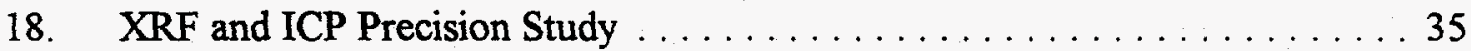

19. Comparison of XRF to ICP Analyses for $\mathrm{Ce}$ and $\mathrm{Cr} \ldots \ldots \ldots \ldots, \ldots \ldots$

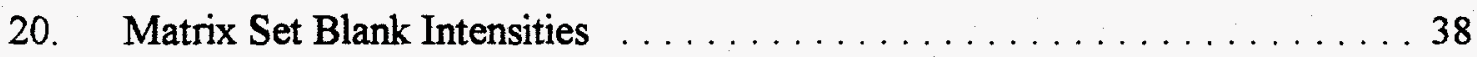

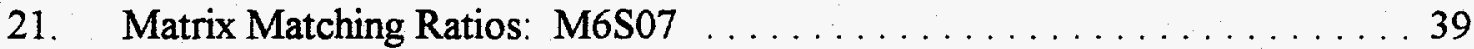

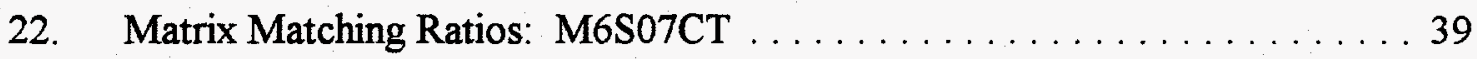

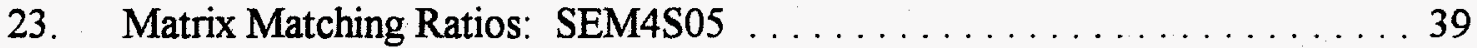

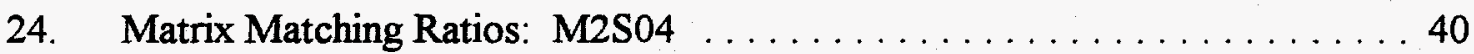

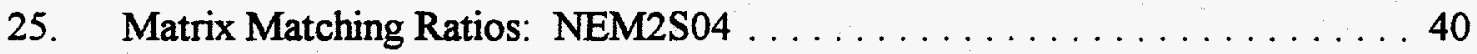

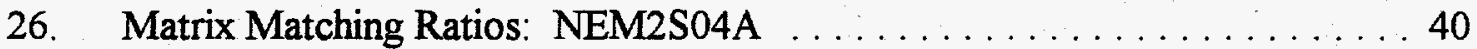

27. Ce Analyses Using Matrix Matched Standards ............... 41

28. Comparison of ICP-AES and XRF Results Using Matrix 


\section{LIST OF TABLES}

(Contd.)

Page

29. X-ray Intensities for Standard Matching $\ldots \ldots \ldots \ldots \ldots \ldots \ldots$

30. Slag Core Cerium Analyses (XRF Data, MAHS 10/94) . . . . . . . 44 


\title{
THE EVALUATION OF THE X-RAY FLUORESCENCE (XRF) TECHNIQUE FOR PROCESS MONITORING OF VITREOUS SLAG FROM THERMAL WASTE TREATMENT SYSTEMS: A COMPARATIVE STUDY OF THE ANALYSIS OF PLASMA HEARTH SLAG FOR CE, FE AND CR BY XRF AND INDUCTIVELY COUPLED PLASMA SPECTROMETRIES
}

by

M. A. H. Sutton, P. J. Crane, D. G. Cummings and K. P. Carney

\begin{abstract}
Slag material produced by the Plasma Hearth Process (PHP) varies in chemical composition due to the heterogeneous nature of the input sample feed. $\mathrm{X}$-ray fluorescence (XRF) is a spectroscopic technique which has been evaluated to perform elemental analyses on surrogate slag material for process control. Vitreous slag samples were ground to a fine powder in an impact ball mill and analyzed directly using laboratory prepared standards. The fluorescent intensities of $\mathrm{Si}, \mathrm{Al}$ and $\mathrm{Fe}$ in the slag samples was utilized to determine the appropriate matrix standard set for the determination of $\mathrm{Ce}$. The samples were analyzed for $\mathrm{Cr}, \mathrm{Ni}, \mathrm{Fe}$ and $\mathrm{Ce}$ using a wavelength dispersive XRF polychromator. Split samples were dissolved and analyzed by Inductively Coupled PlasmaAtomic Emission Spectrometry (ICP-AES).

The precision of the XRF technique was better than 5\% RSD. The limit of detection for Ce varied with sample matrix and was typically below $0.01 \%$ by weight. The linear dynamic range for the technique was evaluated over two orders of magnitude. Typical calibration standards ranged from $0.01 \% \mathrm{Ce}$ to $1 \% \mathrm{Ce}$. The Ce determinations performed directly on ground slag material by the XRF technique were similar to ICP-AES analyses. Various chemical dissolution and sample preparation techniques were evaluated for the analysis of $\mathrm{Ce}$ in slag samples. A fusion procedure utilizing $\mathrm{LiBO}_{2}$ was found to provide reliable analyses for the actinide surrogate in a variety of slag matrices. The use of the XRF technique reduced the time of analysis for $\mathrm{Ce}$ and $\mathrm{Cr}$ from three days to one day for five samples. No additional waste streams were created from the analyses by the XRF technique, while the ICP technique generated several liters of liquid waste.
\end{abstract}




\section{INTRODUCTION}

$\mathrm{X}$-ray fluorescence spectrometry has been evaluated as a technique to provide rapid, inexpensive elemental analyses of vitreous slag produced during the development and operation of thermal waste treatment systems. The development of these waste processing systems requires extensive chemical analyses in order to determine the partitioning behavior of radionuclides and their chemical surrogates. The operation of the final processing system will require routine analyses to insure that the system produces an acceptable, consistent waste form for disposal. The cost for analytical services associated with the development and operation of these thermal waste treatment systems could far exceed their development costs. The objective of this work was to evaluate the capabilities of the XRF technique to provide inexpensively, timely analyses for $\mathrm{Ce}, \mathrm{Cr}, \mathrm{Ni}$ and $\mathrm{Fe}$ in slag produced by the Plasma Hearth Process. Then, if successful, the technique will be evaluated for

the analyses of $\mathrm{U}, \mathrm{Pu}$, and other RCRA metals in waste forms derived from the processing of radioactive wastes. The ultimate end goal is to produce a technique which can be used to determine the elemental composition of the slag material during the actual processing of wastes in an industrial scale processing plant.

\section{A. PROCESS MONITORING REOUIREMENTS}

The following criteria have been established for the monitoring of vitreous slag produced in a continuous manner by the plasma hearth process:

1) The technique must be capable of simultaneous multi-elemental analysis. The technique must be capable of determining elemental compositions over a wide range of concentrations. The predicted concentration range extends from the part per million to major percent levels.

2) The techniques must be at least semi-quantitative with an analysis precision better than $10 \%$ relative standard deviation. A quantitative measurement is preferred. 
3) Due to the radioactive nature of the waste forms, non-intrusive methods of analyses and techniques which minimize sample preparation are desired. A direct solid sampling technique is preferable.

4) The technique must have a relatively short analysis turnaround time.

5) The instrumentation must be capable of operating in an uncontrolled, industrial environment.

6) The technique must be automated and operator friendly for process monitoring in an industrial environment.

7) The technique must be capable of real or near real time analyses.

The XRF technique is a multi-elemental simultaneous analysis technique which is capable of performing analyses directly on liquid and solid samples. The technique has been used for quantitation of elemental composition at trace, minor and major component levels. X-ray fluorescence is a nondestructive technique which is based on the penetration of $\mathrm{x}$-rays from a source into a sample. The x-rays interact with and eject inner core electrons from the elements in the matrix. Electrons cascade to fill the vacancies within the inner core, and as a result, energy is released in the form of photons which have characteristic energies distinct to each element. The energy range for these photons extends from $100 \mathrm{eV}$ to $100 \mathrm{keV}$. These $\mathrm{x}$-rays may be absorbed to a significant degree by matrix elements, detector windows or the atmosphere prior to reaching the detector. For this reason, matrix matched standards are necessary for calibration.

Sample preparation is relatively easy and fast in comparison to classical wet chemical digestions. For this reason, the $\mathrm{X}$-ray technique has been applied extensively for process control in many industrial applications. The commercial instrumentation available is mature technology, 
easily operated by technicians in industrial settings and requires little or no spectral interpretation. As such, $\mathrm{x}$-ray fluorescence was chosen as a technique which may provide automated elemental analysis of vitreous slag material for process control of the slag end-product of the plasma hearth process. The technique is rapid, inexpensive to operate and produces little or no additional waste streams to the plasma hearth process. The following sections discuss the application of the XRF technique to perform analyses on materials which are similar to the PHP slag product.

\section{B. REVIEW OF XRF ANALYSES}

$\mathrm{X}$-ray fluorescence is a nondestructive analysis technique which is capable of performing quantitative measurements on trace, minor and major elemental constituents. XRF has been touted as one of the most versatile and inexpensive techniques in analytical chemistry. ${ }^{1}$ The XRF technique has been used for the elemental analysis of a variety of matrices which are quite similar to the chemistry of the slag produced by the Plasma Hearth Process. Dalton and Smith ${ }^{2}$ have utilized an energy dispersive XRF spectrometer to determine $\mathrm{Ti}, \mathrm{V}, \mathrm{Cr}, \mathrm{Mn}, \mathrm{Fe}, \mathrm{Co}, \mathrm{Se}, \mathrm{Sr}, \mathrm{Y}, \mathrm{Zr}, \mathrm{Mo}, \mathrm{Cu}, \mathrm{Zn}$, $\mathrm{Pb}, \mathrm{Ni}, \mathrm{As}$, Th and $\mathrm{U}$ at microgram levels in airborne particulate. Bower ${ }^{3}$ used a wavelength dispersive polychromator system for the determination of 23 elements (including $\mathrm{Ce}$ ) in silicate rocks. Labrecque and Schorin ${ }^{4}$ determined $\mathrm{A} 1, \mathrm{Si}, \mathrm{Ti}$ and $\mathrm{Fe}$ in Venezuelan laterites which contained titanium dioxide ranging from $2 \%$ to $4 \%$ in an aluminum oxide, iron oxide and silicon dioxide matrix. Each oxide was present at levels ranging from $20 \%$ to $30 \%$ by weight. Jones and Wilson ${ }^{5}$ used a wavelength dispersive polychromator system to analyze for $\mathrm{Fe}, \mathrm{Ca}, \mathrm{Si}, \mathrm{Al}$ and $\mathrm{Mg}$ at major percent levels in magnesite and dolomite matrices. Zimmerman and Lalonde ${ }^{6}$ used the XRF technique to

\footnotetext{
${ }^{1}$ He, F.; Van Espen, P.J., Anal. Chem., 63:2237-2244 (1991).

${ }^{2}$ Smith, C.W.; Dalton, J.L., Can. J. Spectrosc., 24:163-171 (1979).

${ }^{3}$ Bower, N.W., Appl. Spectrosc., 39:697-703 (1985).

${ }^{4}$ Labrecque, J.J.; Schorin, H., Appl. Spectrosc., 34:39-43 (1980).

5 Jones, M.H.; Wilson, B.W., Analyst, 116:449-451 (1991).

6 Zimmerman, J.B.; Lalonde, C.R., Can. J. Spectrosc., 22:99-102 (1977).
} 
determine $\mathrm{Al}, \mathrm{Si}, \mathrm{Ca}, \mathrm{Fe}$ and $\mathrm{Ti}$ in a series of shales, slates and slag matrices. Lalonde and Dalton ${ }^{7}$ used the XRF technique to determine $\mathrm{Ce}, \mathrm{Yt}$ and $\mathrm{Th}$ in mineral samples. Balaes et al. ${ }^{8}$ determined .13 elements ranging from $0.02 \%$ to $25 \%$ levels in Ta-Nb-Sn slags. Thorium has been determined in ore samples at levels ranging from 0.1 to $4 \%$ by weight. ${ }^{9}$ Of particular interest to waste processing has been the development of methods to determine $\mathrm{U}$ and $\mathrm{Pu}$ in ores and nuclear grade materials. ${ }^{10}$

\section{REVIEW OF ON-LINE XRF MONITORING CAPABILITIES}

The capability to determine the elemental composition of the slag material produced by thermal processing systems has been identified as an important method for analyzing physical properties of the slag such as viscosity. ${ }^{11}$ As stated in the review, XRF can be used for the on-line monitoring of the slag. From an operational standpoint, batch samples can be pulled from the melt and analyzed with minimal delays. This information may be used to control both the processing and the quality of the waste form.

7 Lalonde, C.R.; Dalton, J.L., Can. J. Spectrosc., 27:163-170 (1982).

8 Balaes, A.M.E.; Dixon, K.; Wall, G.J., Appl. Spectrosc., 41:509-512 (1987).

9 Zimmerman, J.B.; Lalonde, C.R., Can. J. Spectrosc., 23:156-159 (1978).

10 Reilly, D.: Ensslin, N.; Smith, H. Jr.; Kreiner, S., "Passive Nondestructive Assay of Nuclear Materials," Office of Nuclear Regulatory Research, NUREG/CR-5550, U.S. Government Printing Office (1991).

11 Queneau, D.B.; Cregar, D.E.; Karwaski, L.D., Pollution Engineering, 26-32 (January 15, 1992). 
An alternative to batch sampling of the melt is to perform the XRF analyses in-situ. On-line applications of the XRF technique have been applied to monitoring jet aircraft engine wear ${ }^{12}$, monitoring actinide waste processing streams, ${ }^{13}$ and determination of $\mathrm{Cr}$ in boreholes. ${ }^{14}$

\section{REVIEW OF SAMPLE PREPARATION PROCEDURES FOR XRF ANALYSIS}

Sample preparation techniques for XRF spectrometry can range from simply measuring the sample with no prior sample preparation to requiring complete chemical dissolution and chemical separations to eliminate matrix interferences. Numerous methods for direct analysis ${ }^{11-13,15}$ of material without the need for sample preparation have been developed for industrial determinations. Uranium has been determined directly in ore samples with minimal sample preparation using an energy dispersive XRF system. ${ }^{16}$ Compton scattering was utilized to correct for changes in matrix absorption.

A common method for preparing samples for XRF measurements is to dilute the matrix in a flux such as lithium tetraborate. ${ }^{3,8,17}$ The dilution minimizes the absorption and enhancement effects which may be caused by the sample matrix, and reduces the number of standards necessary

${ }^{12}$ Packer, L.; Jarvingen, M.; Sipila, H., Anal. Chem., 59:1427-1433 (1985).

13 Day, R.; Vigil, A., submitted to J. Radioanal. Nucl. Chem. (December 1995).

14 Reeves, "Development of an XRF Probe: Application to the Determination of $\mathrm{Cr}$ in Boreholes," presented to ANS MARC III Symposium, Kailua-Kona, Hawaii (April 1994). To be published in J. Radioanal. Nucl. Chem. (December 1995).

15 He, F.; Van Espen, P.J., Anal. Chem., 63:2237-2244 (1991).

16 Rowson, J.W.; Honteas, S.A., Can. J. Spectrosc., 22:24-30 (1977).

17 Jones, M.H.; Wilson, B.W., "Rapid Method for the Determination of the Major Components of Magnesite, Dolomite and Related Materials by X-ray Spectrometry," Analyst, 116:449-451 (1991). 
quantification. The complexities of developing an expert system based on the XRF technique are primarily due to the problems associated with sample preparation for a wide variety of sample types. ${ }^{18}$

\section{E. REVIEW OF CHEMICAL DIGESTION PROCEDURES FOR ICP-AES}

Sample dissolution techniques must be selected according to the elements desired for analysis and their corresponding matrices. Fundamental discussions for sample decomposition techniques have been published. ${ }^{19,20}$ The geochemical, metallurgical and environmental analysis literature is abundant with classical procedures for the analysis of $U$, Th and rare earth elements ${ }^{21}$ in silicate matrices. Yamashige et al..$^{22}$ and Wang et al. ${ }^{23}$ have performed a comprehensive study of acid dissolution and $\mathrm{Na}_{2} \mathrm{O}$ fusion based sample decomposition techniques for the elemental analysis of atmospheric particulates.

18 van den Bogaert, B.; Morsink, J.B.W.; Smit, H.C., Anal. Chim. Acta, 270:115-130 (1992).

19 Vogel, A.I., "Vogel's Textbook of Quantitative Chemical Analysis", Fifth Edition, Jeffery, G.H., Bassett, J.; Mendham, J.; Denny, R.C., Editors, Longman Scientific and Technical, UK (1989).

20 Maxwell, J., "Rock and Mineral Analysis," Elving, P.J.; Kolthoff, I.M., Editors, Interscience Publishers, John Wiley and Sons, NY (1968).

21 Rivoldini, A.; Fadda, S., "Inductively Coupled Plasma Mass Spectrometric Determination of Low-Level Rare Earth Elements in Rocks Using Potassium-Based Fluxes for Sample Decomposition," J. Anal. Atom. Spectrosc., 9:519-524 (1994).

22 Yamashige, T.; Yamamoto, M.; Sunahara, H., "Comparison of Decomposition Methods for the Analysis of Atmospheric Particulates by Atomic Absorption Spectrometry," Analyst, 114:1071-1077 (1989).

${ }^{23}$ Wang, C.F.; Miau, T.T.; Perng, J.Y.; Yeh, S.J.; Chiang, P.C.; Tsai, H.T., Yang, M.H., "Multi-Elemental Analysis of Airborne Particulate Matter by Inductively Coupled Plasma Atomic Emission Spectrometry," Analyst, 114:1067-1069 (1989). 
Fluxes have been used commonly to dissolve silicate and alumina based materials. Fluxes have also been used extensively for $\mathrm{x}$-ray fluorescence analyses. Of particular interest to the analysis of wastes from thermal treatment systems is the analysis of refractory ore and smelter samples ${ }^{24}$, calcined bauxite, ${ }^{25}$ alumina matrices and refractory oxides, ${ }^{26}$ magnesites and dolomites.

The analysis of $\mathrm{Ce}$, which is used as a surrogate element for plutonium, complicates chemical digestion procedures in silicate material. It is well documented that $\mathrm{Ce}$ forms an insoluble fluoride complex. This complexation technique is used widely for the gravimetric separation of rare earth elements. Typically, the resulting precipitate will be filtered and scintered with sodium peroxide or sodium carbonate, then dissolved in hydrochloric acid. ${ }^{27}$ Furthermore, $\mathrm{CeO}_{2}$ is only slightly soluble in alkali fluxes thus eliminating the use of sodium carbonate fluxes. ${ }^{20}$ However, $\mathrm{Ce}$ is soluble in lithium and potassium meta- and tetraborate fluxes. After fusion with a suitable flux, the mixture is then dissolved in $6 \mathrm{~N}$ hydrochloric or nitric acid. ${ }^{20}$ Sample dissolution techniques using hydrofluoric acids such as Parr bomb and microwave dissolution may be applicable to the analysis of $\mathrm{U}$ and $\mathrm{Pu}$ in slag material. Chemical decomposition techniques have been compared rigorously by Yamashige ${ }^{19}$ for the determination of $\mathrm{Ba}, \mathrm{Cr}, \mathrm{Si}, \mathrm{Ti}, \mathrm{Al}, \mathrm{Ca}, \mathrm{Co}, \mathrm{Fe}, \mathrm{Mg}, \mathrm{Mn}, \mathrm{Ni}, \mathrm{V}, \mathrm{K}, \mathrm{Li}, \mathrm{Na}, \mathrm{Cd}, \mathrm{Cu}, \mathrm{Pb}, \mathrm{Zn}$, $\mathrm{As}$ and $\mathrm{Sb}$ in atmospheric particulate using nine different acid combinations.

${ }^{24}$ Bozic, J.; Maskery, D.; Maggs, S.; Susil, H.; Smith, F.E., "Rapid Procedure for the Dissolution of Ore and Smelter Samples Prior to Analysis by Inductively Coupled Plasma Atomic Emission Spectrometry," Analyst, 114:1401-1403 (1989).

25 Coedo, A.G.; Fuentes, F.J.V., "Application of Inductively Coupled Plasma Spectrometry (ICP) to the Analysis of Calcined Bauxites," Appl. Spectrosc., 39:24-27 (1985).

26 Balaes, A.M.E.; Dixon, K.; Wall, G.J., "Application of X-ray Fluorescence Spectrometry to the Analysis of Ta-Nb-Sn Slags and Associated By-products," Appl. Spectrosc., 41:509512 (1987).

27 Pukhavskaya, V.A.; Maryutina, T.A.; Grebneva, O.N.; Kuz'min, N.M.; Spivakov, B.Ya., Spectrochim. Acta, 48B:1365-1370 (1993). 


\section{EXPERIMENTAL}

\section{A. CHEMICAL REAGENTS}

Reagent grade magnesium oxide, iron (III) oxide, silica, cerium nitrate, hexa-hydrate and alumina were obtained from J. T. Baker Chemical, Phillipsburg, NJ. ICP single element plasma standards were obtained from Spec Industries, Edison, NJ.

\section{B. XRF STANDARD AND SAMPLE PREPARATION}

1) Preparation of Interelement Interference Check Standards

Analytes which were selected for the polychromator system $(\mathrm{Cr}, \mathrm{Ni}, \mathrm{Pb}, \mathrm{Cd}, \mathrm{Si}, \mathrm{Fe}, \mathrm{Al}$ and $\mathrm{Ce}$ ) were spiked at the $100 \mu \mathrm{g} \mathrm{g}^{-1}$ level into a finely ground silica gel matrix. The spiked samples were split into equal portions: one series was saved as a control standard and the other was spiked with a suspected interfering element.

2) Ce Standards in Powdered Form

Powder standards were prepared by weighting directly various masses of Magnesium Oxide, Iron (III) Oxide, Silica, Cerium Nitrate Nexa-hydrate, Cadmium Oxide, Lead Dioxide, Nickel Oxide, Chromium Oxide and Alumina. All reagents were obtained from J. T. Baker Chemical, Phillipsburg, NJ. Each standard was mixed in a ball mill for approximately 20 minutes.

3) Powdered Slag Sample Preparation

Slag samples were obtained from Scientific Applications International Corporation (SAIC). The slag samples were produced from the processing of simulated waste 
formulations containing $\mathrm{CeO}$ as an actinide surrogate. Samples of the slag were obtained by crushing the slag in a hydraulic press. A random sampling of the fractured sample was taken and ground further using a ball mill. The required processing of the samples in the ball mill varied from 20 minutes to 40 minutes. Metal encapsulated in the slag was identified and removed by visual inspection. One to two gram quantities of each standard or sample were placed in disposable XRF sample containers. The XRF sample cup window was six micron thick mylar.

\section{ICP-AES SAMPLE AND STANDARD PREPARATION}

A series of mixed element standards containing $\mathrm{Ce}, \mathrm{Al}, \mathrm{Ni}, \mathrm{Cr}, \mathrm{Co}$, and $\mathrm{Mn}$ for the calibration of the ICP were prepared in $10 \% \mathrm{HCl}, 10 \% \mathrm{HNO}_{3}$.

Portions of the powdered slag samples which were prepared previously were weighed, mixed with a known mass of $\mathrm{LiBO}_{2}$ in a 10:1 ratio (flux to sample) and fused. The fused samples were then dissolved in $6 \mathrm{~N} \mathrm{HCl}$, diluted to volume in volumetric glassware with $10 \%$ nitric, $10 \%$ hydrochloric acid and then analyzed by ICP-AES.

PHP slag samples were ground to a fine powder ( $<100$ mesh). Aliquots ( 0.5 gram) of each sample were fused with lithium metaborate, then dissolved in $6 \mathrm{~N} \mathrm{HCl}$. The resulting solutions diluted to volume in volumetric glassware with $10 \%$ nitric, $10 \%$ hydrochloric acid and were analyzed for $\mathrm{Cr}, \mathrm{Ni}, \mathrm{Fe}, \mathrm{Co}, \mathrm{Ce}$ and $\mathrm{Al}$ by FIA-ICP-AES.

\section{FLOW INJECTION-INDUCTIVELY COUPLED PLASMA SPECTROMETER}

Dissolved slag samples were analyzed for $\mathrm{Al}, \mathrm{Ce}, \mathrm{Fe}, \mathrm{Co}, \mathrm{Cr}$ and $\mathrm{Ni}$ using an argon segmented flow injection--inductively coupled plasma spectrometer system with a $25 \mu 1$ injection volume. The spectrometer system consisted of a 13-channel polychromator and a $1.0 \mathrm{~m}$ scanning monochromator. A laboratory constructed data collection system was utilized to obtain time resolved flow injection 
elution profiles. Cerium analyses were also performed using the monochromator in a scanning mode. Plasma operating parameters used to obtain the data shown in Table 1. Spectral wavelengths used to monitor analyte emission are provided in Table 2. Polychromator and monochromator operating parameters are shown in Table 3. Flow injection profiles were processed using Chromperfect software.

TABLE 1. Plasma Operating Parameters

RF Forward Power

RF Reflected Power

Ar Coolant Flow Rate

Ar Plasma Flow Rate

Nebulizer Flow Rate

Nebulizer Uptake Rate
$1000 \mathrm{~W}$

$<5 \mathrm{~W}$

$121 \mathrm{~min}^{-1}$

$0.31 \mathrm{~min}^{-1}$

$0.51 \mathrm{~min}^{-1}$

$2.0 \mathrm{ml} \mathrm{min}^{-1}$

TABLE 2. ICP Analyte Wavelengths

Element

$\mathrm{Ce}$

$\mathrm{Fe}$

$\mathrm{Cr}$

$\mathrm{Ni}$

Al

Co
Wavelength (nm) Order

$\begin{array}{ll}413.8 & 1 \\ 259.9 & 1 \\ 205.5 & 1 \\ 216.5 & 1 \\ 396.1 & 1 \\ 228.6 & 1\end{array}$


TABLE 3. ICP Spectrometer Operating Parameters

Monochromator: JY38, Jobin Yvon, Edison, NJ

Monochromator Band Pass $\quad 0.001 \mathrm{~nm}$

Monochromator PMT Voltage $\quad 650 \mathrm{~V}$

Grating $3600 \mathrm{~g} \mathrm{~mm}^{-1}$

Polychromator: JY32, Jobin Yvon, Edison, NJ

Polychromator Band Pass $\quad 0.002 \mathrm{~nm}$

Grating $1200 \mathrm{~g} \mathrm{~mm}^{-1}$

One problem associated with the use of fluxing reagents is that the resulting solutions contain a relatively high dissolved solids content $(>1-2 \%)$. This often causes problems with the nebulization and detection of trace analytes in the dissolved sample. The method of standard additions was performed in order to investigate whether the dissolved flux matrix had an effect on the determination of $\mathrm{Ce}$. Three aliquots of a dissolved sample (M6S07) were spiked with a known mass of Ce. Each spiked standard was analyzed using the ICP technique under identical operating conditions. The slope of the calibration line obtained from the method of standard additions was identical to the slope of the calibration curve obtained using standards prepared in $10 \% \mathrm{HC} 1$. The $\mathrm{Ce}$ concentration obtained from the method of standard additions was equivalent to the result obtained from conventional analyses. This implies that the addition of the flux matrix to the samples does not introduce any interferenes with the ICP-AES determination of Ce. The results from the

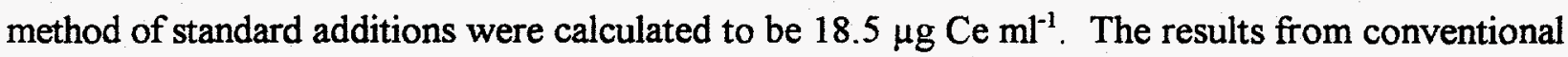
analyses were calculated to be $19.4 \mu \mathrm{g} \mathrm{Ce} \mathrm{ml}^{-1}$. The standard addition calibration curve is shown in Fig. 1. 
Fig. 1. Method of Standard Additions for $\mathrm{Ce}$ in $\mathrm{LiBO}_{2}$ Solutions

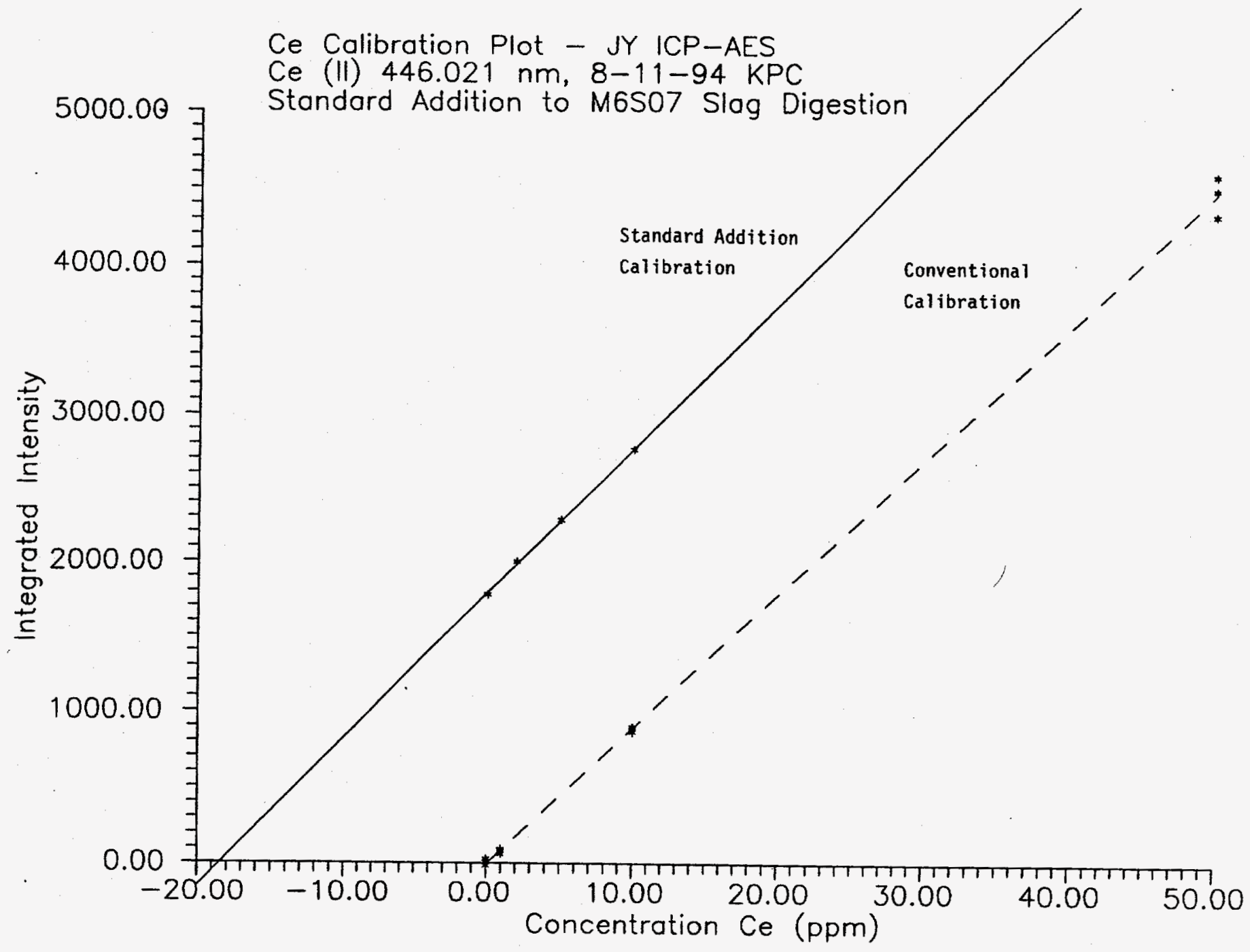




\section{E. XRF OPERATING PARAMETERS}

$\mathrm{X}$-ray fluorescence analysis of vitreous slag from the $\mathrm{PH}$ process was performed using an Oxford QX simultaneous wavelength-dispersive spectrometer. The spectrometer contained eight independent crystal analyzers equipped with either gas flow- or sealed proportional counters. A 200 watt rhodium tube was used as an excitation source. Spectrometer operating parameters are given in Table 4.

TABLE 4. XRF Spectrometer Operating Parameters

X-ray Tube Target ....... Rh

Tube Voltage $\ldots \ldots \ldots .50 \mathrm{kV}$

Tube Current ........ $4 \mathrm{~mA}$

\begin{tabular}{|c|c|c|c|}
\hline Element & Wavelength (Angstroms) & 2 Theta & Crystal \\
\hline $\mathrm{Fe}$ & 1.937 & 57.5 & $\mathrm{LiF} 200$ \\
\hline $\mathrm{Ce}$ & 2.561 & 79.0 & $\mathrm{LiF} 200$ \\
\hline $\mathbf{N}$ & 1.659 & 48.7 & $\mathrm{LiF} 200$ \\
\hline $\mathrm{Cr}$ & 2.291 & 69.4 & $\mathrm{LiF} 200$ \\
\hline $\mathrm{Pb}$ & 0.982 & 28.2 & LiF200 \\
\hline $\mathrm{Si}$ & 7.126 & 144.6 & $\mathrm{InSb}$ \\
\hline $\mathrm{Al}$ & 8.339 & 144.5 & PE \\
\hline
\end{tabular}




\section{RESULTS AND DISCUSSION}

\section{A. XRF SPECTROMETER RESOLUTION}

A polychromator system equipped with dedicated crystal analyzers was selected because of the exceptional resolution obtainable with the system, and the simplicity of the detection and data collection systems. However, fixed element crystal analyzers are subject to spectral interferences from order overlap and transitions which have very similar energy differences. The situation is analogous to spectral overlap interferences encountered in emission spectroscopy using low resolution polychromator systems. The resolution of each crystal analyzer will be one of the major factors influencing the accuracy of the determinations by the XRF instrument. This is most important in the 10-14 keV range for the determination of Th, $\mathrm{U}, \mathrm{Np}$ and $\mathrm{Pu}$. The separation in energy of these elements is on the order of $100 \mathrm{eV}$. A list of the interfering elements, the energies of the analyte and energies of the interfering elements are shown in Appendix A, Table 3.

The uncorrected counts per second for the analyte only, and analyte containing the interferant are given in Table 5. Notice in all cases that the interferant did not effect the analyte signals.

The resolution capabilities of the $\mathrm{LiF}(200)$ crystal was demonstrated further using the variable channel scanning monochromator. A spectral scan was obtained from sample containing $5 \%$ cerium nitrite hexahydrate and $5 \%$ titanium dioxide which was fused with lithium metaborate. The spectrum obtained (shown in Fig. 2) shows that the Ce L peak (4.83keV) at a 2 Theta angle of $79.02^{\circ}$ is clearly resolved from the Ti K $\beta$ peak ( $4.95 \mathrm{keV}$ ) at a 2 Theta angle of $77^{\circ}$. These two peaks are separated by an energy difference of $102 \mathrm{eV}$. 
TABLE 5. Effect of Interferants on XRF Analyte Signals

\begin{tabular}{|c|c|c|}
\hline Analyte & Analyte Only & Analyte w/Interant \\
\hline $\mathrm{Cd}$ & 153 & 159 \\
\hline $\mathrm{Cr}$ & 1079 & 1032 \\
\hline $\mathrm{Ni}$ & 2932 & 2933 \\
\hline $\mathrm{Ce}$ & 72 & 76 \\
\hline $\mathrm{Fe}$ & 1861 & 1770 \\
\hline
\end{tabular}

All intensities are reported in $\underline{\text { Cnts } ~^{-1}}$ 
Fig. 2. XRF Resolution Scan: $\mathrm{Ce}$ and $\mathrm{Ti}$

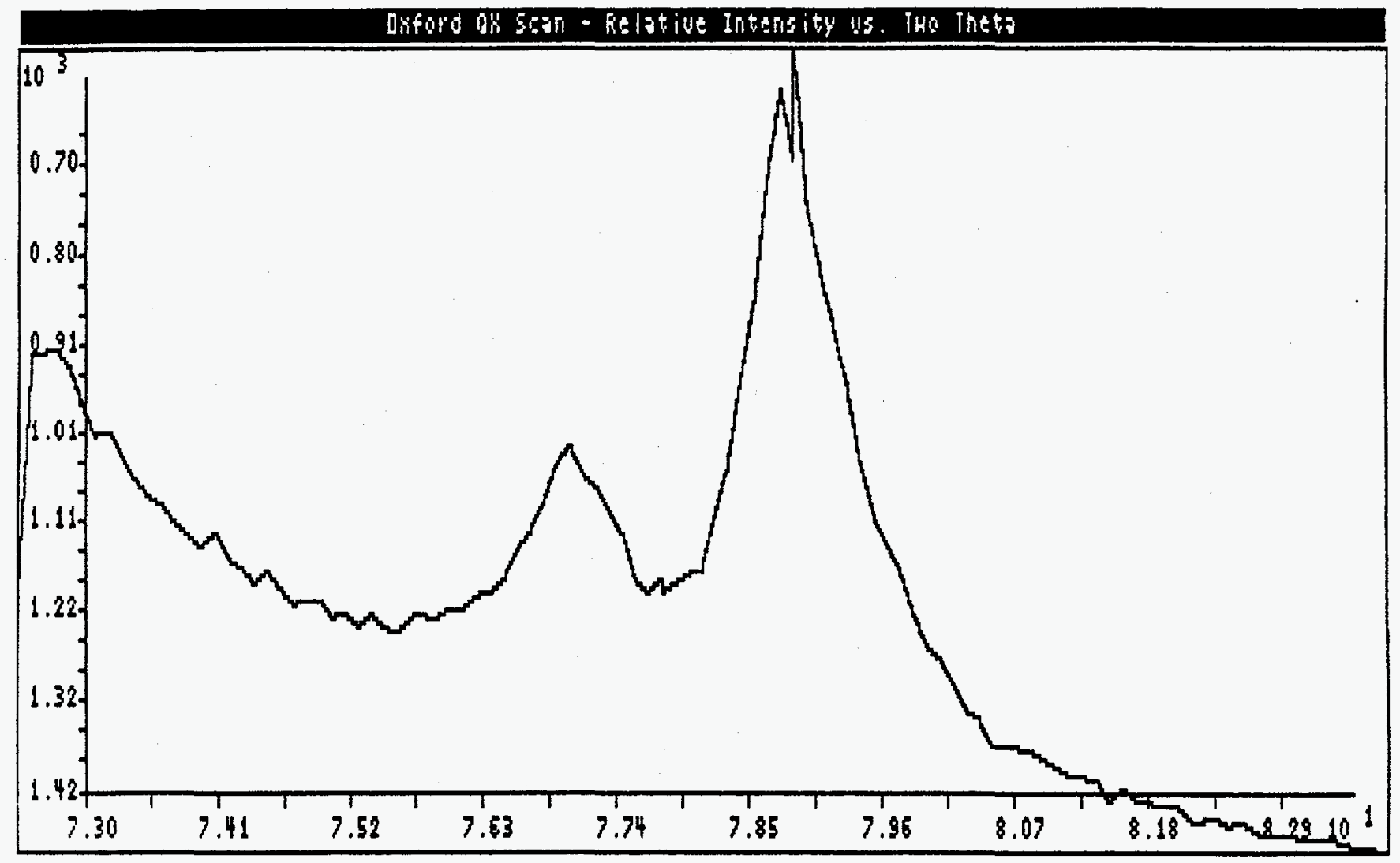




\section{B. XRF LIMITS OF DETECTION FOR TRACE ELEMENTS IN GLASS}

The expected concentrations of actinide elements in the vitrous slag from the processing of low level and transuranic mixed wastes depend upon the element and their respective isotopes. Calculations were performed based on the specific activity of selected isotopes. The upper concentration range which can be expected for $\mathrm{Pu}$ is $100 \mathrm{ug} \mathrm{g}^{-1}$, while the upper limits for Th and $\mathrm{U}$ are on the order of several percent.

Levels of RCRA metals may vary from ppm levels to percent levels in the slag. Limits of detection for the analytes which were determined for $\mathrm{Fe}, \mathrm{Ni}, \mathrm{U}$ and $\mathrm{Pb}$ using NIST glass standards. LODs are reported in Table 6.

TABLE 6. Estimated XRF Limits of Detection

\begin{tabular}{|c|c|c|c|}
\hline Element & Limit of Detection* & B.E.C. & $Q$ \\
\hline $\mathrm{U}$ & 9 ppm & $865 \mathrm{ppm}$ & $0.46 \mathrm{cnts} / \mathrm{ppm}$ \\
\hline $\mathrm{Fe}$ & $7 \mathrm{ppm}$ & 752 ppm & $0.76 \mathrm{cnts} / \mathrm{ppm}$ \\
\hline $\mathrm{Ni}$ & $3 \mathrm{ppm}$ & $292 \mathrm{ppm}$ & $1.35 \mathrm{cnts} / \mathrm{ppm}$ \\
\hline $\mathrm{Pb}$ & $5 \mathrm{ppm}$ & 962 ppm & $1.88 \mathrm{cnts} / \mathrm{ppm}$ \\
\hline \multicolumn{4}{|c|}{${ }^{*} \mathrm{LOD}=3 *\left[\text { B.E.C. } /\left(\mathrm{Q}^{*} \mathrm{t}\right)\right]^{1 / 2}, \mathrm{t}=200 \mathrm{~s}$} \\
\hline \multicolumn{4}{|c|}{ B.E.C. $=$ Background Equivalent Concentration } \\
\hline
\end{tabular}

\section{CHEMICAL ANALYSIS OF PLASMA HEARTH SLAG BY ICP-AES}

Chemical analyses were performed on various samples of slag obtained from SAIC. Fusion methods were evaluated for slag analyses. Five plasma hearth samples were fused with lithium metaborate $\left(\mathrm{LiBO}_{2}\right)$ and sodium carbonate $\left(\mathrm{Na}_{2} \mathrm{CO}_{3}\right)$. Unfortunately, as stated previously, cerium oxide is only slightly soluble in the $\mathrm{Na}_{2} \mathrm{CO}_{3}$ flux. This resulted in incomplete dissolution of the slag samples. The precipitate was filtered, dried and identified as cerium oxide using x-ray diffraction. 
The presence of interelement interferences due to spectral overlap was evaluated by nebulizing pure single element standards and comparing the resulting time resolved emission profiles with that of a solution blank. The presence of spectral interferences from major matrix elements such as $\mathrm{Fe}$, $\mathrm{Mg}, \mathrm{Al}$ and $\mathrm{Si}$ on $\mathrm{Cr}, \mathrm{Ni}, \mathrm{Co}$ and $\mathrm{Ce}$ were evaluated. The chromium emission line suffered no observable interference from any of the matrix standards. Nickel was influenced by the presence of iron. A $600 \mathrm{ppm} \mathrm{Fe}$ solution resulted in the equivalent concentration of $\mathrm{Ni}$ equal to approximately $2 \mathrm{ppm}$. Iron was measured in solution at concentrations ranging from 30 to $830 \mathrm{ppm}$.

The results from ICP-AES analyses are listed in Table 7 through 10. The precision of the analyses varied between elements within each sample as well as between the samples. For instance, four independent analyses of slag M4S05 by ICP-AES resulted in an apparent bi-modal concentration distribution. Two samples contained $\mathrm{Cr}$ at levels of $0.14 \%$, while the other two analyses were reported at levels of 0.24 and $0.35 \%$. In the same slag sample the iron composition also varied in a bi-modal distribution, but not in the same sequence. This indicates that, from a chemist's point of view, the samples are fairly heterogeneous and not simply prone to a systematic error. 
$-19-$

TABLE 7. FIA-ICP-AES Slag Analyses: M2SO4 (Elemental Weight \%)

\begin{tabular}{|l|c|c|c|c|c|c|}
\hline Slag: & M2SO4 & & & & & $\begin{array}{l}\text { FIA Data } \\
\text {-Fused } \\
\text { PHP Slag } \\
\text { Samples }\end{array}$ \\
\hline & $\mathrm{Ce}$ & $\mathrm{Fe}$ & $\mathrm{Cr}$ & $\mathrm{Ni}$ & $\mathrm{Co}$ & $\mathrm{Al}$ \\
\hline & 0.200 & 19.090 & 0.078 & 0.078 & 0.009 & 4.750 \\
\hline & 0.191 & 17.720 & 0.091 & 0.077 & 0.024 & 4.470 \\
\hline Average & 0.196 & 18.405 & 0.085 & 0.078 & 0.017 & 4.610 \\
\hline \% RSD & --- & -- & - & -- & - & - \\
\hline
\end{tabular}

TABLE 8. FIA-ICP-AES Slag Analyses: M2SO2 (Elemental Weight \%)

\begin{tabular}{|c|c|c|c|c|c|c|}
\hline & $\mathbf{C e}$ & $\mathbf{F e}$ & $\mathbf{C r}$ & $\mathbf{N i}$ & $\mathbf{C o}$ & $\mathbf{A l}$ \\
\hline & 0.100 & 15.720 & 0.044 & 0.070 & 0.010 & 2.910 \\
\hline & 0.120 & 13.210 & 0.039 & 0.060 & 0.100 & 3.090 \\
\hline & 0.160 & 19.780 & 0.054 & 0.089 & 0.020 & 3.930 \\
\hline & 0.090 & 15.970 & 0.044 & 0.047 & 0.013 & 3.040 \\
\hline & 0.103 & 16.390 & 0.047 & 0.074 & 0.013 & 3.180 \\
\hline Average & 0.115 & 16.214 & 0.046 & 0.068 & 0.031 & 3.230 \\
\hline \% RSD & 24.069 & 14.489 & 12.071 & 23.089 & 123.832 & 12.486 \\
\hline
\end{tabular}


$-20-$

TABLE 9. FIA-ICP-AES Slag Analyses: M6SO7 (Elemental Weight \%)

\begin{tabular}{|c|c|c|c|c|c|c|}
\hline & $\mathbf{C e}$ & $\mathbf{F e}$ & $\mathbf{C r}$ & $\mathbf{N i}$ & $\mathbf{C o}$ & $\mathbf{A l}$ \\
\hline & 0.410 & 5.210 & 0.044 & 0.078 & 0.011 & 8.460 \\
\hline & 0.420 & 5.170 & 0.051 & 0.121 & 0.023 & 7.770 \\
\hline & 0.360 & 4.320 & 0.040 & 0.049 & 0.009 & 7.370 \\
\hline & 0.410 & 4.790 & 0.044 & 0.056 & 0.008 & 7.980 \\
\hline & 0.330 & 4.420 & 0.034 & 0.052 & 0.080 & 7.290 \\
\hline Average & 0.386 & 4.782 & 0.043 & 0.071 & 0.026 & 7.774 \\
\hline \% RSD & 10.133 & 8.611 & 14.622 & 42.245 & 117.064 & 6.137 \\
\hline
\end{tabular}

TABLE 10. FIA-ICP-AES Slag Analyses: M4SO5 (Elemental Weight \%)

\begin{tabular}{|c|c|c|c|c|c|c|}
\hline Slag: & M4SO5 & & & & & \\
\hline & $\mathbf{C e}$ & $\mathbf{F e}$ & $\mathbf{C r}$ & $\mathbf{N i}$ & $\mathbf{C o}$ & $\mathbf{A l}$ \\
\hline & 0.170 & 1.770 & 0.141 & 0.083 & 0.006 & 6.730 \\
\hline & 0.130 & 1.150 & 0.035 & 0.042 & 0.010 & 6.340 \\
\hline & 0.160 & 18.720 & 0.141 & 0.077 & 0.005 & 6.470 \\
\hline & 1.030 & 10.210 & 0.024 & 0.046 & 0.003 & 6.180 \\
\hline Average & 0.373 & 7.963 & 0.085 & 0.062 & 0.006 & 6.430 \\
\hline \% RSD & 117.762 & 103.951 & 75.696 & 33.858 & 49.065 & 3.616 \\
\hline
\end{tabular}


TABLE 11. XRF Standard Composition (Elemental Weight \%)

\begin{tabular}{|c|c|c|c|c|}
\hline Set & \% Si & \% Al & \% Fe & \% $\mathbf{M g}$ \\
\hline 1 & 24.5 & 1.9 & 16.7 & 12.2 \\
\hline 2 & 22.9 & 8.9 & 13.8 & 8.6 \\
\hline 3 & 22.2 & 9.7 & 3.5 & 17.5 \\
\hline 4 & 33.0 & 3.2 & 0.0 & 14.0 \\
\hline 5 & 32.4 & 5.2 & 6.3 & 7.1 \\
\hline 6 & 32.0 & 8.7 & 10.6 & 0.0 \\
\hline 7 & 32.0 & 10.8 & 3.7 & 3.5 \\
\hline
\end{tabular}

TABLE 12. Ce XRF Calibration Results

\begin{tabular}{|c|c|c|c|}
\hline Set & $\mathbf{m}\left(\right.$ Cnts $\left.^{-1}\right)$ & b (cnts) & Corr. \\
\hline 1 & 195 & 74 & 0.9946 \\
\hline 2 & 184 & 61 & 0.9994 \\
\hline 3 & 209 & 49 & 0.9999 \\
\hline 4 & 105 & 47 & 0.9998 \\
\hline 5 & 205 & 48 & 0.9997 \\
\hline 6 & 208 & 52 & 0.9997 \\
\hline 7 & 203 & 48 & 0.9990 \\
\hline Composite & 198 & 55 & 0.9969 \\
\hline
\end{tabular}


This is clearly evident by visual inspection of the sample. In contrast, the precision of the analyses for sample M6SO7 was typically better than 10\% RSD for Ce, Fe and $\mathrm{Al}$. The variation in the $\mathrm{Cr}$ content was less than $15 \%$ RSD.

Values for $\mathrm{Cr}$ and $\mathrm{Ni}$ were at least a factor of two higher than results reported by SAIC obtained from a commercial laboratory analysis. A high iron content was noted in dissolved slag samples M2SO4 (828 ppm Fe), M2SO2 (394 ppm Fe), and M6SO7 (171 ppm Fe). This results in an overestimation of the quantity of $\mathrm{Ni}$ reported in the slag. Consequently, efforts will be made to quantify the effect of the iron interference on the $\mathrm{Ni}$ analyses.

\section{DETERMINATION OF CE, FE AND CR IN PLASMA HEARTH SLAG BY XRF SPECTROMETRY}

An initial study was performed to investigate the effect of varying the matrix composition upon the determination of Ce. A series of 7 matrices were prepared (shown in Table 11) and divided into five sub-samples. Each sub-sample was spiked with various quantities of cerium nitrate. No other metals were added to the mixtures. The integration time was $60 \mathrm{~s}$. The precision obtained from triplicate measurements on each standard after shaking was generally better than $1 \% \mathrm{RSD}$. The corresponding slope, intercept and correlation coefficient from the linear regression of each matrix set is shown in Table 13.

Notice that, with the exception of set four, the matrix formulation has little effect on the slope or intercept of the calibration function. This is surprising due to the wide composition of the matrices. Matrix 4 differs from the others in that it does not contain iron oxide. This may contribute to differences in the packing density of the loose powders (mainly containing $\mathrm{MgO}$ ). The result may cause a change in slope of analyte calibration functions. This may be corrected for by rationing the Ce intensity to the intensity of the $\mathrm{Rh}$ compton scattered radiation. 
A composite plot (Fig. 3) was made for the 35 iron containing standards. The plot was linear for Ce standards ranging in concentration from $170 \mathrm{ppm}$ to $5 \%$ Ce by weight.

Fig. 3. Ce XRF Composite Calibration Curve

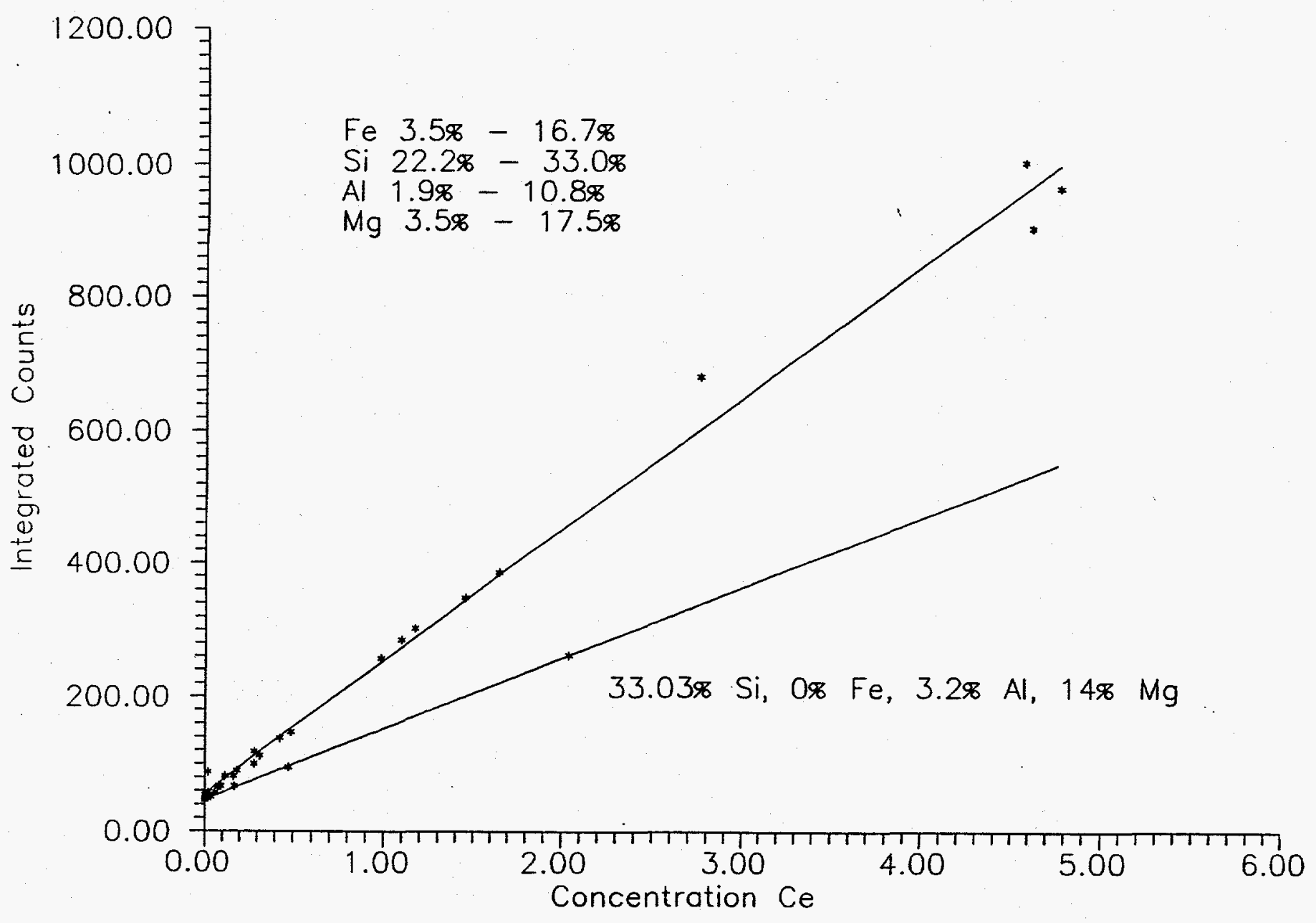


The Ce concentration, in four slag samples was determined using the linear regression parameters obtained from the composite of the standards. The analysis results for $\mathrm{Ce}$ are shown in Table 13, along with results from corresponding ICP-AES analyses. In general, the results obtained using the XRF technique agree fairly well with those obtained by ICP-AES. It must be recognized that these samples, though from the same slag matrix, may be different due to spatial inhomogeneities of the slag sample.

A calibration plot for iron was obtained using the average integrated iron intensity from each blank from the 6 standard sets. The curve (shown in Fig. 4) was non-linear and a logarithmic fit was used to obtain Fe concentrations in the slag material. The results from the XRF analyses are compared to Fe analysis results provided by SAIC of the slag material (Table 13). The results of the $\mathrm{XRF}$ analyses agree with those obtained by wet chemical analysis, given the heterogeneous nature of the samples. 
Fig. 4. Fe XRF Calibration Curve

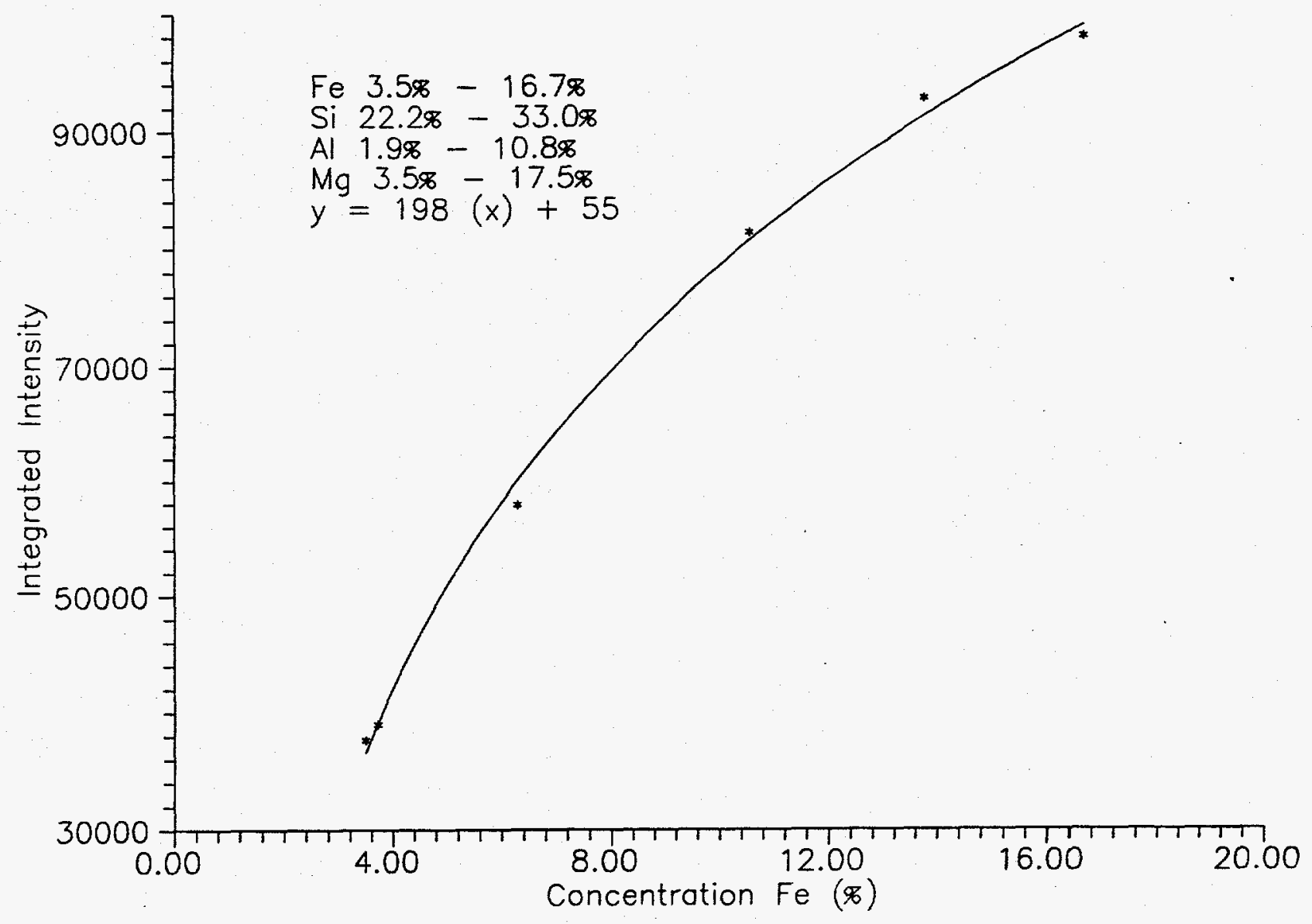

TABLE 13. Fe and Ce Analyses

\begin{tabular}{|c|c|c|c|c|}
\hline Sample & $\begin{array}{c}\text { Ce (wt.\%) } \\
\text { XRF }\end{array}$ & ICP-AES & $\begin{array}{c}\text { Fe (wt.\%) } \\
\text { XRF }\end{array}$ & ICP-AES \\
\hline 1 & 0.33 & 0.25 & 23.2 & 23.8 \\
\hline 2 & 0.34 & 0.29 & 9.8 & 8.5 \\
\hline 3 & 0.27 & 0.25 & 2.2 & 1.7 \\
\hline 4 & 0.44 & 0.59 & 4.5 & 4.6 \\
\hline
\end{tabular}




\section{E. XRF ANALYSIS OF SYNTHETIC STANDARDS FOR CERIUM, CHROMIUM, NICKEL, LEAD AND CADMIUM}

The XRF technique was evaluated to measure $\mathrm{Ni}, \mathrm{Cd}, \mathrm{Pb}$ and $\mathrm{Cr}$. Three sets of six laboratory prepared standards were analyzed. The major element composition of the standards is reported in Table 14. The integrated intensity for various standards containing different masses of $\mathrm{Ce}, \mathrm{Ni}, \mathrm{Pb}$, $\mathrm{Cd}$ and $\mathrm{Cr}$ was measured. Replicate measurements were obtained for each calibration standard and plotted as a function of weight percent for each matrix (see Figures 5 through 8). It is interesting to examine the results for each element as a function of its matrix. Consider matrix 1 and 2 , which have essentially the same silica and alumina content matrix. However, the iron and magnesium content are varied. As expected, the sensitivity (slope of the calibration function) is dependent upon the matrix composition for each element investigated. For $\mathrm{Pb}$ (Fig. 5) and $\mathrm{Ni}$ (Fig. 6) the slope of the calibration function for matrix set 1 is approximately twice that of the slope obtained for matrix set 2 over the same concentration range. However, the response for $\mathrm{Cr}$ (Fig. 7) appears to be independent from the sample matrix. this is not the case if one compares the $\mathrm{Cr}$ response for matrix set 1 and 2 to that of set 3. This behavior is also noted for Ce. In Fig. 8, Ce is quantified over a range from $0.025 \%$ to $0.12 \%$. However, the $\mathrm{Ce}$ response for matrix set 3 for the high standard $(0.12 \% \mathrm{Ce})$ is not statistically different from the matrix blank in set 3 . This set of standards is being re-measured to confirm this observation. This only emphasizes the need for a broad range of matrix matched standards.

TABLE 14. Matrix Composition

Weight Percent Element

\begin{tabular}{|c|c|c|c|c|}
\hline Matrix Set & \% Fe & \% Mg & \% Si & \% Al \\
\hline 1 & 21.0 & 30.1 & 6.4 & 5.3 \\
\hline 2 & 38.5 & 6.0 & 6.4 & 7.9 \\
\hline 3 & 39.9 & 27.2 & 6.4 & 5.0 \\
\hline
\end{tabular}


Fig. 5. $\mathrm{Pb}$ XRF Calibration Curve

Matrix $2 A \& 3 A, P b$ LB $0.982 \mathrm{~A}$

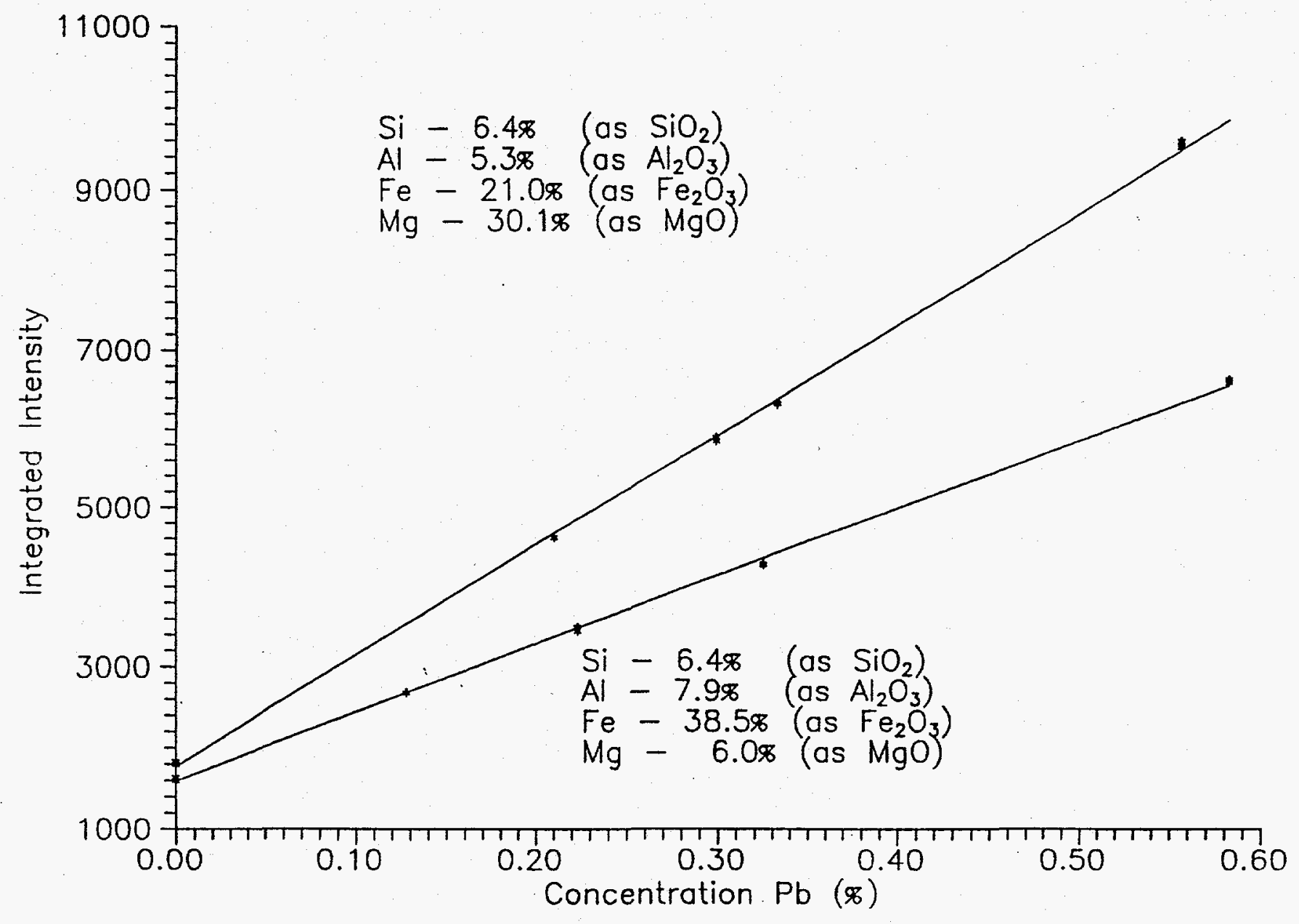


Fig. 6. Ni XRF Calibration Curve

Ni Calibration Plot - Powder

Matrix 2A, Ni K , 1.659 A

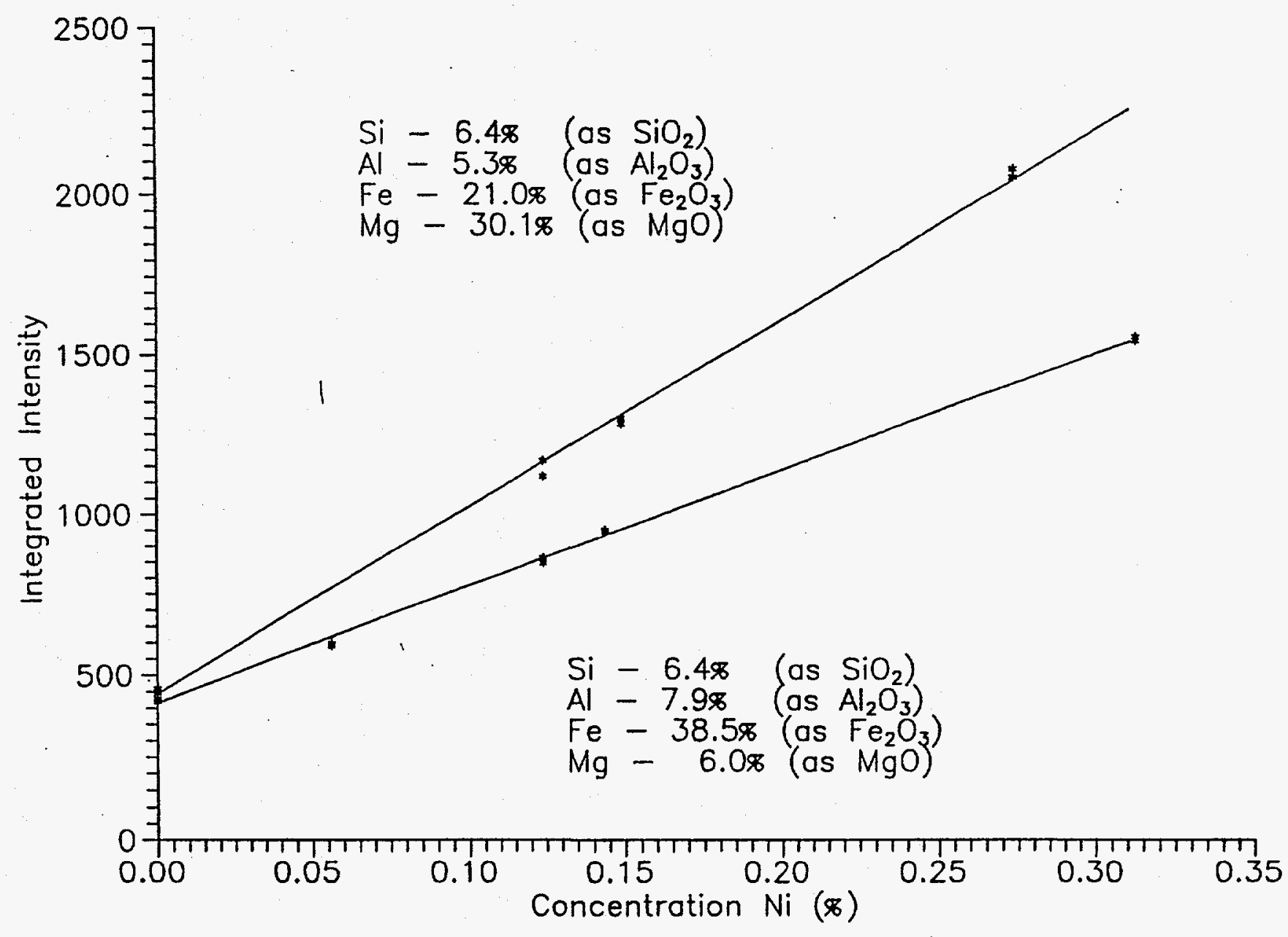


Fig. 7. Cr XRF Calibration Curve

Cr Calibration Plot - Powder

Matrix 2A, $\mathrm{Cr} \mathrm{K}, 2.291 \mathrm{~A}$

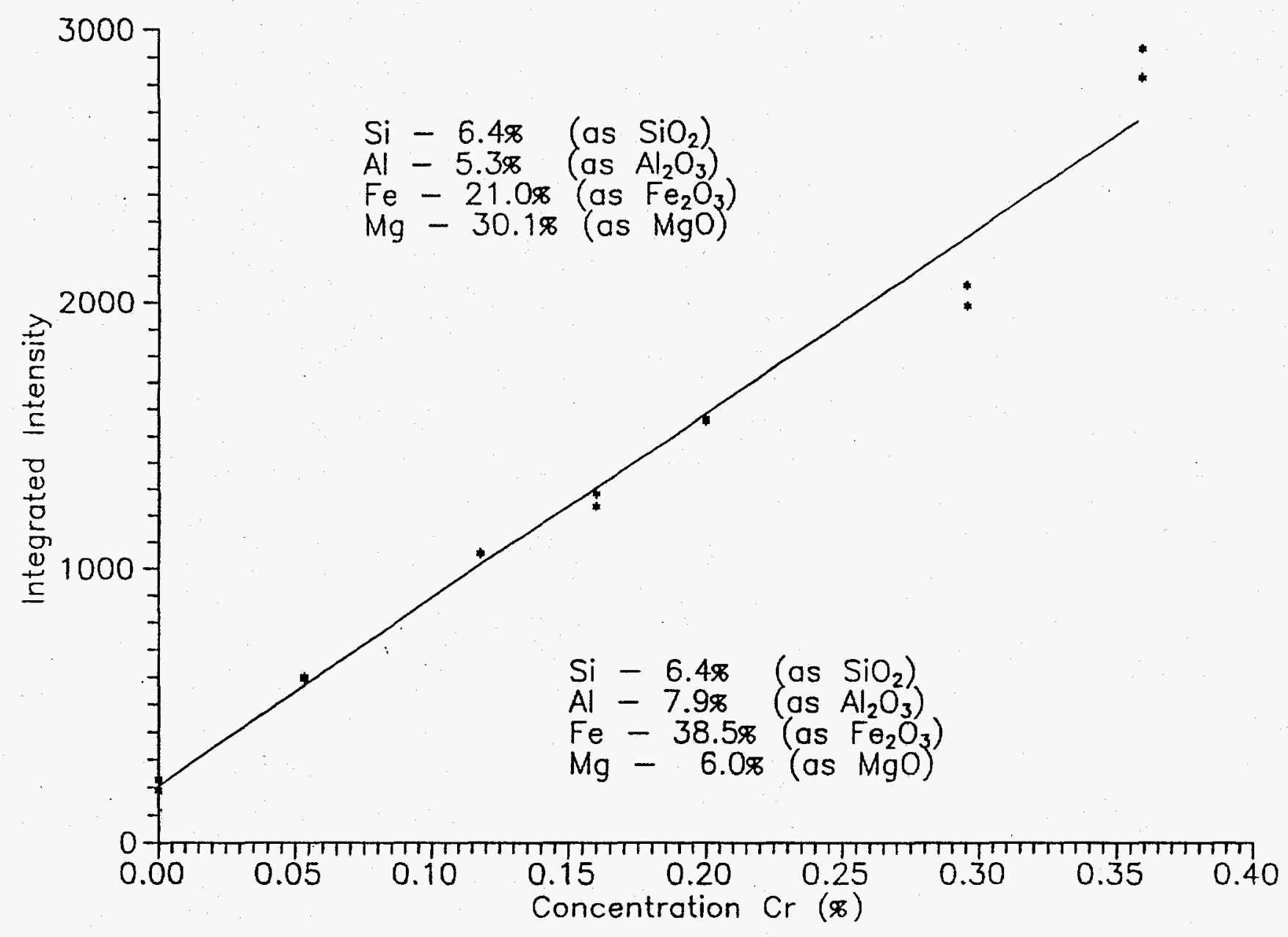


Fig. 8. Ce CRF Calibration Curve

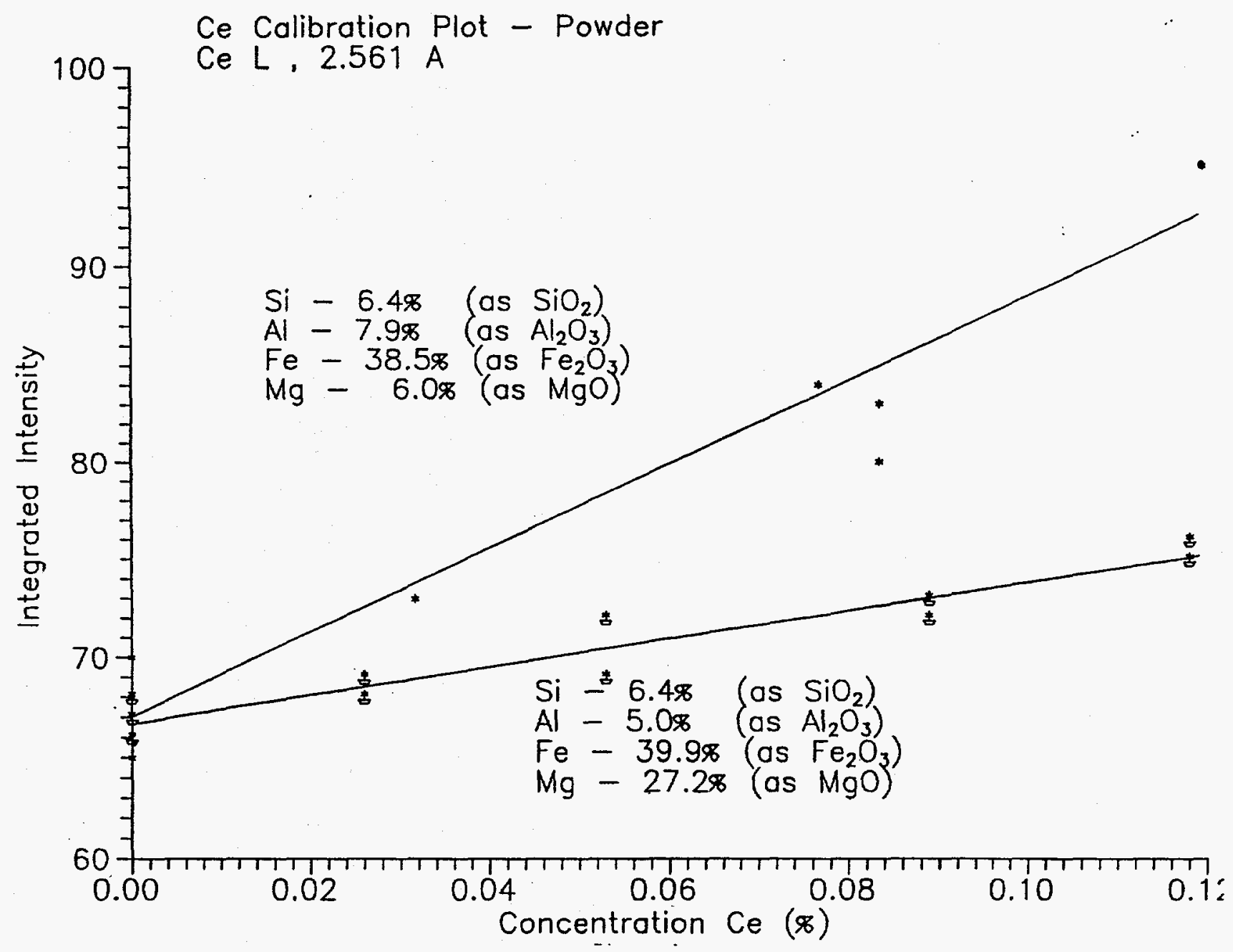




\section{F. DETERMINATION OF CE AND CR IN PHP SLAG BY XRF SPECTROMETRY}

Results from corresponding XRF analyses for $\mathrm{Ni}, \mathrm{Cr}$ and $\mathrm{Ce}$ are reported ini Tables 15 through 17. The $\mathrm{Cr}, \mathrm{Ce}$ and $\mathrm{Ni}$ concentrations were obtained using a single standard matrix that contained $3.2 \% \mathrm{Si}, 2.7 \% \mathrm{Al}, 10.4 \% \mathrm{Fe}$, and $15.0 \% \mathrm{Mg}$. A rhodium $\mathrm{x}$-ray tube was operated at a voltage of $50 \mathrm{kV}$ and $4 \mathrm{~mA}$. The integration time was $60 \mathrm{~s}$. All standards and samples were prepared as pressed pellets. The calculated concentration and concentration interval at the $95 \%$ confidence level for the samples are provided in Tables 15 through 17. The limit of detection (LOD) for $\mathrm{Cr}$ was estimated at $95 \%$ confidence level to be 0.018 percent by weight. Notice that all the calculated values for $\mathrm{Cr}$ were below the estimated LOD. The LOD for Ce was estimated at $95 \%$ confidence level to be $0.010 \%$ by weight. The LOD for Ni was estimated at $95 \%$ confidence level to be 0.003 percent by weight. This was calculated based on the method detailed by Hubaux and $\operatorname{Vos}^{28}$. Results for the analysis of $\mathrm{Ni}$ and $\mathrm{Cr}$ were at or lower than the limit of detection. This may be an affect of the sample matrix on the fluorescence intensity emitted from the lithium tetraborate containing $\mathrm{La}$ as a heavy absorber. This should dilute out the effects of the sample matrix and possibly enhance the signal from $\mathrm{Cr}$ and $\mathrm{Ni}$.

28 A. Hubaux, G. Vos, Anal. Chem., 42:849 (1970). 
TABLE 15. Cr XRF Analysis Results

Sample

M2S04-1

M2S04-2

M2S04-3
Average Intensity

433.0000

426.0000

437.0000

Average wt. $\% \mathrm{Cr}$ : M2S04:<0.02\%

M6S07-1

M6S07-2

M6S07-3

Average wt. $\%$ Cr: M6S07: $<0.02 \%$

M4S05-1

M4S05-2

M4S05-3

362.0000

358.0000

374.0000

Average wt.\% Cr: M4S05: < 0.02

$\mathrm{M} 2 \mathrm{~S} 02-1$

$\mathrm{M} 2 \mathrm{~S} 02-2$

$\mathrm{M} 2 \mathrm{~S} 02-3$

Average wt.\% Cr: M2S02: 0.022
473.0000

450.0000

$\begin{array}{ll}462.0000 \\ \text { S02: } & 0.022\end{array}$
Concentration Range

$<0.02$

$<0.02$

$<0.02$

$<0.02$

$<0.02$

$<0.02$

$<0.02$

$<0.02$

$<0.02$

$0.002<0.023<0.044$

$0.000<0.021<0.042$

$0.001<0.022<0.043$ 
TABLE 16. Ce XRF Analysis Results

$\begin{array}{lrl}\text { Sample } & \text { Average Intensity } & \text { Concentration Range } \\ \text { M2S04-1 } & 120.0000 & 0.15<0.19<0.23 \\ \text { M2S04-2 } & 121.0000 & 0.15<0.20<0.24 \\ \text { M2S04-3 } & 121.0000 & 0.15<0.20<0.24 \\ \text { Average wt.\% Ce: } & \text { M2S04: } 0.20 & \\ & & \\ \text { M6S07-1 } & 124.0000 & 0.16<0.21<0.25 \\ \text { M6S07-2 } & 124.0000 & 0.16<0.21<0.25 \\ \text { M6S07-3 } & 127.0000 & 0.17<0.22<0.27 \\ \text { Average wt.\% Ce: } \text { M6S07: } 0.21 & \\ & & \\ \text { M4S05-1 } & 95.0000 & 0.07<0.10<0.12 \\ \text { M4S05-2 } & 94.0000 & 0.07<0.09<0.11 \\ \text { M4S05-3 } & 94.0000 & 0.07<0.09<0.11 \\ \text { Average wt.\% Ce: } \text { M4S05: } 0.09 & \\ & & \\ \text { M2S02-1 } & 99.0000 & 0.06<0.11<0.16 \\ \text { M2S02-2 } & 97.0000 & 0.06<0.11<0.15 \\ \text { M2S02-3 } & 97.0000 & 0.06<0.11<0.15 \\ \text { Average wt.\% Ce: } \text { M2S02: } 0.11 & \end{array}$


$-34-$

TABLE 17. Ni XRF Analysis Results

\begin{tabular}{lcc} 
Sample & Average Intensity & Concentration Range \\
\cline { 2 - 2 } & 522.0000 & $<0.003$ \\
M2S04-2 & 518.0000 & $<0.003$ \\
M2S04-3 & 520.0000 & $<0.003$ \\
Average wt.\% Ni: M2S04: $<0.003$ & \\
M6S07-1 & 492.0000 & $<0.003$ \\
M6S07-2 & 491.0000 & $<0.003$ \\
M6S07-3 & 487.0000 & $<0.003$ \\
Average wt.\% Ni: M6S07: <0.003 & \\
& & \\
M4S05-1 & 591.0000 & $0.002<0.008<0.014$ \\
M4S05-2 & 605.0000 & $0.003<0.009<0.015$ \\
M4S05-3 & 598.0000 & $0.003<0.009<0.015$ \\
Average wt.\% Ni: M4S05: 0.009 & \\
& & \\
M2S02-1 & 535.0000 & $<0.003$ \\
M2S02-2 & 535.0000 & $<0.003$ \\
M2S02-3 & 538.0000 & $<0.003$ \\
Average wt.\% Ni: M2S02: $<0.003$ &
\end{tabular}


$\mathrm{Ce}$ analyses appear to be consistent with data obtained from ICP-AES analyses. The precision of the $\mathrm{Ce}$ analyses by $\mathrm{XRF}$ is better than $5 \% \mathrm{RSD}$. This is attributed to the large sampling area of the XRF instrument which integrates over a large volume of sample. A comparison of values for Ce obtained by XRF and ICP-AES are reported in Tables 18 and 19.

TABLE 18. XRF and ICP Precision Study

\begin{tabular}{|c|c|c|c|}
\hline Slag Type & Sample & XRF Ce (\% by wt.) & $\begin{array}{c}\text { ICP-AES Ce } \\
\text { (\% by wt.) }\end{array}$ \\
\hline M2S04 & 1 & 0.19 & 0.20 \\
\hline M2S04 & 2 & 0.20 & 0.19 \\
\hline M2S04 & 3 & 0.20 & - \\
\hline M6S07 & 1 & 0.21 & 0.41 \\
\hline M6S07 & 2 & 0.21 & 0.42 \\
\hline M6S07 & 3 & 0.22 & 0.36 \\
\hline M4S05 & 1 & 0.10 & 0.17 \\
\hline M4S05 & 2 & 0.09 & 0.13 \\
\hline M4S05 & 3 & 0.09 & 0.16 \\
\hline M2S02 & 1 & 0.11 & 0.10 \\
\hline M2S02 & 2 & 0.11 & 0.12 \\
\hline M2S02 & 3 & 0.11 & 0.16 \\
\hline
\end{tabular}


TABLE 19. Comparison of XRF to ICP Analyses for $\mathrm{Ce}$ and $\mathrm{Cr}$

\begin{tabular}{|c|ccccc|}
\hline Slag & \multicolumn{2}{|c|}{ Ce } & \multicolumn{2}{c|}{ Cr } \\
& $\underline{\text { XRF }}$ & $\underline{\text { ICP-AES }}$ & $\underline{\text { XRF }}$ & $\underline{\text { ICP-AES }}$ \\
M2S04 & 0.19 & 0.20 & $<02$ & 0.09 \\
M6S07 & 0.21 & 0.39 & $<0.02$ & 0.04 \\
M2S02 & 0.11 & 0.12 & 0.02 & 0.05 \\
M4S05 & 0.09 & 0.15 & 0.01 & 0.09
\end{tabular}

\section{G. COMPARISON OF XRF TO ICP-AES RESULTS}

$\mathrm{XRF}$ analyses were compared to those obtained using Inductively Coupled Plasma--Atomic Emission Spectrometry. Four slag samples were analyzed in triplicate using both techniques. Results of the analyses are presented in Table 19. It appears that the results from samples $\mathrm{M} 2 \mathrm{SO} 4$ and $\mathrm{M} 2 \mathrm{SO} 2$ (both inorganic sludge) appear to agree quite well. The results of analyses from slag M4SO5 and $\mathrm{M} 6 \mathrm{SO} 7$ from the XRF analyses are lower than the ICP analyses, but still within a factor of two. The precision of the XRF analyses is better than $5 \%$ relative standard deviation (RSD). The ICP results are typically found to be poorer than $10 \%$ RSD. This is most probably due to the limited size of the slag sample dissolved for analysis $(0.5 \mathrm{~g})$. It is estimated that the XRF technique samples approximately 2 grams of slag.

\section{H. EVALUATION OF THE MATRX MATCHING ROUTINE FOR XRF ANALYSES OF PHP SLAG}

A computational method was developed to minimize the potential for operator bias in selecting an appropriate standard set for analyses. The method is based on the relative fluorescence from matrix elements which are subject to different chemical environments. Each matrix will have different absorption and enhancement effects which are reflected in the intensities measured from the unknown sample and standards. Each powder standard has a unique composition and density; thus, the standard selection must be chosen using a measured variable which can compensate for these 
factors. The method uses the measured intensities for $\mathrm{Al}, \mathrm{Si}$ and $\mathrm{Fe}$ obtained under identical measurement conditions for a series of standards sets and unknown slag samples. The ratio of the intensity of each standard set blank to the intensity of the slag sample for each element is calculated. The ratios are then summed for each respective standard set and divided by the number of elements (in this case, three). The resulting standard set which is closest to unity is the closest standard match. If the computed average is $10 \%$ greater than or less than 1.0 (i.e. $<0.9$ or $>1.1$ ), then no standard match is reported and the XRF results should not be used. This is detailed in Tables 23 through 27 for a series of 7 slag samples and a series of slag samples. The results are reported in Table 28. For Sample SEM 4S05 no suitable matrix match was identified. The matching routine could not decide the appropriate standard match for Sample M6S07CBA. In this case, wet chemistry would be necessary to verify the appropriate standard set. The XRF results for the remaining five samples are identical to the ICP results. 
$-38-$

TABLE 20. Matrix Set Blank Intensities

\begin{tabular}{|c|c|c|c|}
\hline Set & Al & Si & Fe \\
\hline 1 & 72 & 590 & 111224 \\
\hline 3 & 258 & 1670 & 144303 \\
\hline 17 & 91 & 4857 & 77119 \\
\hline 18 & 51 & 2667 & 7460 \\
\hline \multicolumn{4}{|c|}{$\mathbf{S i}$} \\
\hline Sample & $\mathbf{A l}$ & $\mathbf{F e}$ \\
\hline M6S07 & 302 & 3719 & 48158 \\
\hline M6S07CBA & 244 & 2905 & 42440 \\
\hline M6S07CTA & 312 & 3620 & 46492 \\
\hline SEM4S05 & 475 & 6165 & 19272 \\
\hline M2S04 & 232 & 3102 & 116208 \\
\hline NEM2S04 & 231 & 3088 & 116424 \\
\hline NEM2S04 & 204 & 3167 & 116717 \\
\hline
\end{tabular}


TABLE 21. Matrix Matching Ratios: M6S07

\begin{tabular}{|c|c|c|c|c|c|c|}
\hline $\begin{array}{c}\text { Stand } \\
\text { Set }\end{array}$ & Al & Si & Fe & Sum & Average & $\begin{array}{c}\text { Selected } \\
\text { Stnd Set }\end{array}$ \\
\hline Set 1 & 0.30 & 0.20 & 2.62 & 3.12 & 1.04 & Yes \\
\hline Set 3 & 1.06 & 0.57 & 3.40 & 5.03 & 1.68 & No \\
\hline Set 17 & 0.37 & 1.67 & 1.82 & 3.86 & 1.29 & No \\
\hline Set 18 & 0.21 & 0.92 & 1.76 & 2.89 & 0.96 & Yes \\
\hline
\end{tabular}

TABLE 22. Matrix Matching Ratios: M6S07CT

\begin{tabular}{|c|c|c|c|c|c|c|}
\hline $\begin{array}{c}\text { Stand } \\
\text { Set }\end{array}$ & Al & Si & Fe & Sum & Average & $\begin{array}{c}\text { Selected } \\
\text { Stnd Set }\end{array}$ \\
\hline Set 1 & 0.23 & 0.16 & 2.39 & 2.78 & 0.93 & Yes \\
\hline Set 3 & 0.83 & 0.46 & 3.10 & 4.39 & 1.46 & No \\
\hline Set 17 & 0.29 & 1.34 & 1.66 & 3.29 & 1.10 & Yes \\
\hline Set 18 & 0.16 & 0.74 & 1.60 & 2.50 & 0.83 & No \\
\hline
\end{tabular}

TABLE 23. Matrix Matching Ratios: SEM4S05

\begin{tabular}{|c|c|c|c|c|c|c|}
\hline $\begin{array}{c}\text { Stand } \\
\text { Set }\end{array}$ & Al & Si & Fe & Sum & Average & $\begin{array}{c}\text { Selected } \\
\text { Stnd Set }\end{array}$ \\
\hline Set 1 & 0.15 & 0.10 & 5.77 & 6.02 & 2.01 & No \\
\hline Set 3 & 0.54 & 0.27 & 7.48 & 8.29 & 2.76 & No \\
\hline Set 17 & 0.19 & 0.79 & 4.00 & 4.98 & 1.66 & No \\
\hline Set 18 & 0.11 & 0.43 & 3.87 & 4.41 & 1.47 & No \\
\hline
\end{tabular}


TABLE 24. Matrix Matching Ratios: M2S04

\begin{tabular}{|c|c|c|c|c|c|c|}
\hline $\begin{array}{c}\text { Stand } \\
\text { Set }\end{array}$ & Al & Si & Fe & Sum & Average & $\begin{array}{c}\text { Selected } \\
\text { Stnd Set }\end{array}$ \\
\hline Set 1 & 0.31 & 0.19 & 0.96 & 1.46 & 0.49 & No \\
\hline Set 3 & 1.11 & 0.54 & 1.24 & 2.89 & 0.96 & Yes \\
\hline Set 17 & 0.39 & 1.57 & 0.66 & 2.62 & 0.87 & No \\
\hline Set 18 & 0.22 & 0.86 & 0.64 & 1.72 & 0.57 & No \\
\hline
\end{tabular}

TABLE 25. Matrix Matching Ratios: NEM2SO4

\begin{tabular}{|c|c|c|c|c|c|c|}
\hline $\begin{array}{c}\text { Stand } \\
\text { Set }\end{array}$ & Al & Si & Fe & Sum & Average & $\begin{array}{c}\text { Selected } \\
\text { Stnd Set }\end{array}$ \\
\hline Set 1 & 0.31 & 0.19 & 0.96 & 1.46 & 0.49 & No \\
\hline Set 3 & 1.12 & 0.54 & 1.24 & 2.90 & 0.97 & Yes \\
\hline Set 17 & 0.39 & 1.57 & 0.66 & 2.62 & 0.87 & No \\
\hline Set 18 & 0.22 & 0.86 & 0.64 & 1.72 & 0.57 & No \\
\hline
\end{tabular}

TABLE 26. Matrix Matching Ratios: NEM2SO4A

\begin{tabular}{|c|c|c|c|c|c|c|}
\hline $\begin{array}{c}\text { Stand } \\
\text { Set }\end{array}$ & Al & Si & Fe & Sum & Average & $\begin{array}{c}\text { Selected } \\
\text { Stnd Set }\end{array}$ \\
\hline Set 1 & 0.35 & 0.19 & 0.95 & 1.46 & 0.49 & No \\
\hline Set 3 & 1.26 & 0.53 & 1.24 & 3.03 & 1.01 & Yes \\
\hline Set 17 & 0.45 & 1.53 & 0.66 & 2.64 & 0.88 & No \\
\hline Set 18 & 0.25 & 0.84 & 0.64 & 1.73 & 0.58 & No \\
\hline
\end{tabular}


TABLE 27. Ce Analyses Using Matrix Matched Standards

\begin{tabular}{|l|c|c|l|}
\hline \multicolumn{1}{|c|}{ Sample } & Avg. Int. & Set \# & Concentration Range 95 CL \\
\hline M6S07CBA & 116.5 & Set 1 & $0.24<0.40<0.57$ \\
\hline M6S07 & 148.5 & Set 17 & $0.26<0.36<0.46$ \\
\hline M6S07CTA & 142.5 & Set 17 & $0.24<0.34<0.44$ \\
\hline M6S07CBA & 116.5 & Set 18 & $0.57<0.75<0.93$ \\
\hline SEM2S05 & No Match Avail. & No Match Avail. & No Match Available \\
\hline M2S04 & 140.5 & Set 3 & $0.20<0.24<0.28$ \\
\hline NEM2S04 & 138.5 & Set 3 & $0.19<0.23<0.27$ \\
\hline NEM2S04A & 121.5 & Set 3 & $0.13<0.16<0.19$ \\
\hline
\end{tabular}

TABLE 28. Comparison of ICP-AES and XRF Results Using Matrix Matching Routine

\begin{tabular}{|c|c|c|}
\hline Slag Type & XRF Ce (\% by wt.) & ICP-AES Ce (\% by wt.) \\
\hline M2S04 & 0.24 & 0.20 \\
\hline NEM2S04 & 0.23 & 0.20 \\
\hline NEM2S04A & 0.16 & 0.20 \\
\hline M6S07 & 0.36 & 0.41 \\
\hline M6S07CTA & 0.34 & 0.39 \\
\hline M6S07CBA & 0.40 or 0.75 & 0.39 \\
\hline SEM4S05 & No Match Available & No Match Available \\
\hline
\end{tabular}




\section{CORE ANALYSES BY ICP-AES AND XRF FOR CE USING MATRIX MATCHING ROUTINE}

A study was performed to evaluate the ability of the technique to perform quantitative analyses of slag obtained from different spatial locations across a slag monolith. The analysis of seven slag core sections was performed using the XRF technique with four different standard sets. Table 29 displays intensity data for 60 second count times which were obtained from the four standard blanks, and slag cores denoted M2S05, M2S06 and M2S07. The relative intensities of the major matrix elements in the sample can be used to select the slag standard set. Set 1 matches well for Fe, but falls short for $\mathrm{Al}$ and $\mathrm{Si}$.

The results shown in Table 30 for the Ce concentrations obtained utilizing standard set 3 (selected by the matrix matching routine) are essentially the same as the ICP results. If standard 1 were selected, then an error in the standard matching would superimpose a bias on the accuracy of the analyses. Notice that sets 1,17 and 18 are offset by up to a factor of three. For comparisons within the same fairly homogeneous monolith, this does not affect the analysis of variance calculations because the bias can be removed by simply coding the data. Absolute accuracy for these exercises is not necessary as long as the bias is consistent from core to core and can be corrected for.

\section{CONCLUSIONS}

The XRF technique has been shown to be capable of producing analysis results that are within the error associated with those obtained through wet chemical digestion and ICP-AES analysis techniques. An automated, operator independent matrix matching routine was developed which provided the successful comparison of XRF to ICP results in 12 of 14 samples. One of the 2 unsuccessful attempts was due to the lack of an appropriate XRF standard. 
The process can analyze 28 standards and 10 slag samples within an eight hour period. Minimal sample preparation is required--simply grinding to a fine powder. The Oxford QX instrument can be operated in an uncontrolled environment with minimum maintenance. This technique can presently be used for the analysis of slag containing $\mathrm{Ce}$ as a surrogate for $\mathrm{Pu}$. This will significantly reduce the costs associated with process development for the plasma hearth testing program.

TABLE 29. X-ray Intensities for Standard Matching

\begin{tabular}{|c|c|c|c|}
\hline Standard/Sample & Al (cnts/min) & Si (cnts/min) & Fe (cnts/min) \\
\hline Set 1 & 101 & 861 & 111998 \\
\hline Set 3 & 272 & 1891 & 142248 \\
\hline Set 17 & 87 & 4573 & 79801 \\
\hline Set 18 & 57 & 3558 & 75283 \\
\hline M2S05T & 248 & 3685 & 113497 \\
\hline M2S05M & 230 & 2647 & 118061 \\
\hline M2S05B & 218 & 2862 & 113693 \\
\hline M2S06B & 334 & 2259 & 123370 \\
\hline M2S06M & 254 & 3143 & 110964 \\
\hline M2S06T & 256 & 3333 & 118859 \\
\hline M2S07 & 242 & 3196 & 116764 \\
\hline
\end{tabular}


TABLE 30. Slag Core Cerium Analyses (XRF Data, MAHS 10/94)

\begin{tabular}{|c|c|c|c|c|c|}
\hline Core & Stnd. 1 & Stnd. 3 & Stnd. 17 & Stnd. 18 & ICP-AES \\
\hline M2S05T & 0.86 & 0.29 & 0.37 & 1.09 & 0.34 \\
\hline M2S05M & 0.67 & 0.27 & 0.35 & 1.03 & 0.27 \\
\hline M2S05B & 0.71 & 0.16 & 0.25 & 0.77 & 0.15 \\
\hline M2S06T & 0.73 & 0.30 & 0.38 & 1.11 & 0.31 \\
\hline M2S06M & 0.50 & 0.18 & 0.27 & 0.83 & 0.18 \\
\hline M2S06B & 0.58 & 0.22 & 0.31 & 0.93 & 0.23 \\
\hline M2S07 & 0.72 & 0.29 & 0.37 & 1.09 & 0.29 \\
\hline
\end{tabular}

\section{FUTURE WORK}

The XRF technique will continue to be evaluated for determining $\mathrm{U}$ and $\mathrm{Pu}$ in slag and particulate produced by the plasma hearth process. The QX instrument is to be adapted for use in a glovebox environment for the analysis of slag and particulate produced during the radioactive testing trials of the Plasma Hearth Process.

\section{ACKNOWLEDGMENTS}

The authors wish to thank the Engineering Division, in particular R. G. Pahl, J. R. Krsul, D. L. Porter, and L. C. Walters for their review of this document. The authors also thank the Waste Management branch of Science Applications International Corporation for supplying the vitreous slag for chemical and XRF analyses. A special thanks has been well earned by P. L. Howell for her efforts in the preparation and publication of this document. 
$-45-$

APPENDIX 
equest for DCN.

CN No.

woll 30-007

ocument No.

w0630-0046-BS-00
Date: $3 / 11 / 94$

Preparedby: Kevin P. Carney

Date: $3 / 11 / 94$

Change

Required by: 3/11/94

DATE

escription of Change:

\section{For specific changes to drawing(s) or specification(s) see DCN continuation sheet(s).}

1. Section $3 \cdot 1 \cdot 3 \cdot 2.2 a$ change to:

Each elemental analyzer will have a bandwidth of $150 \mathrm{eV}$.

2. Eliminate from Section 6.3 notification, the following:

- . If delivery is delayed more than 15 days from the stated delivery date of April 10, 1994, then $5 \%$ of the purchase price will be deducted from the original price for each seven days for which delivery is delayed (weekday not working day).

ustification for Change:

1. Typo.

2. Needs DOE approval. Not justified for purchase.
Work Request No.

Engineering File No.

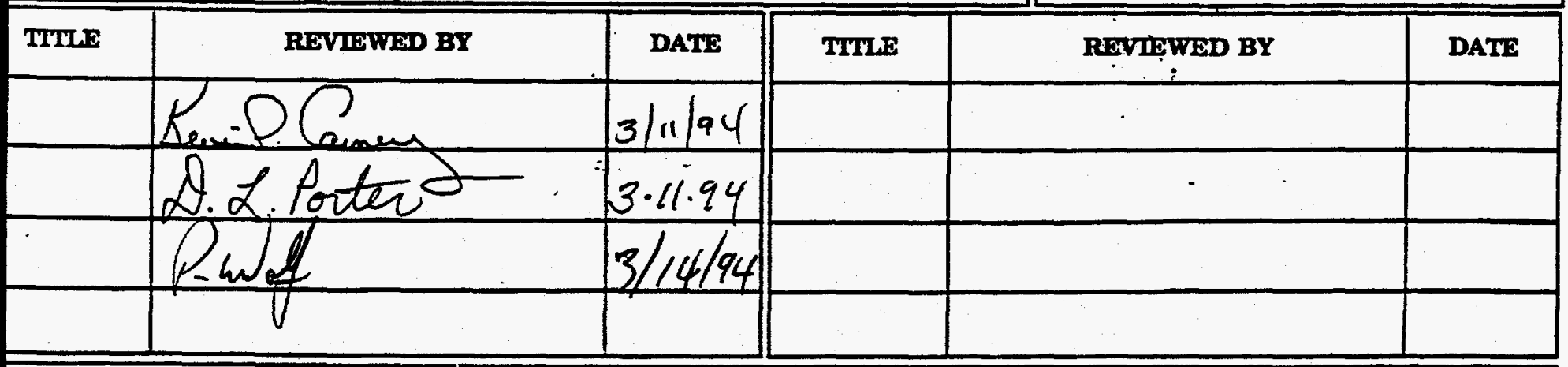

pproved for Release: 


\title{
Analytical Laboratory
}

Fuels and Engineering Division

\author{
Argonne National Laboratory \\ P O Box 2528
}

Idaho Falls, Idaho 83403-2528

TECHNICAL SPECIFICATIONS

FOR

X-RAY FLUORESCENCE SPECTROMETER

Document Control No. W0630-0046-BS-01

Prepared by:

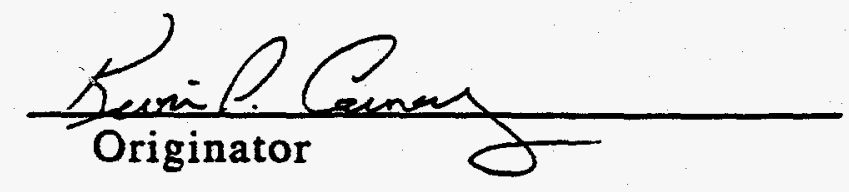

Date: 3/11/94

Approved by:

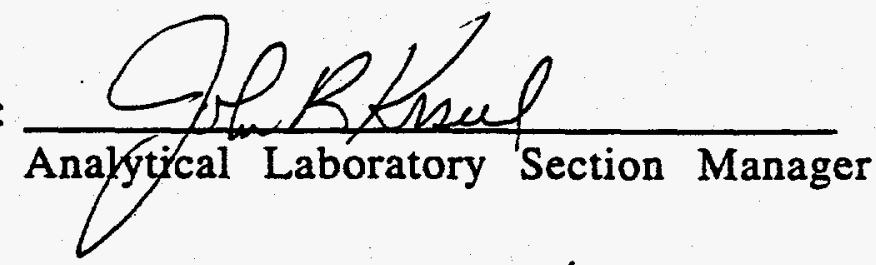

Date: $3 / 11 / 94$

Approved by:

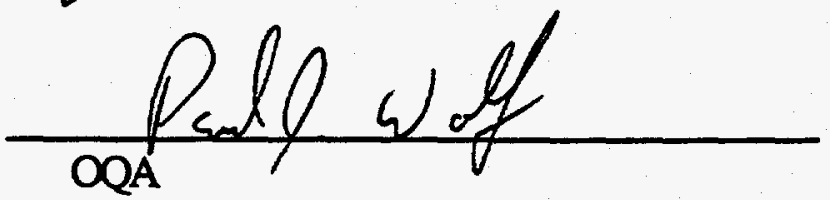

Date: $3 / 14 / 94$

Approved by: $\frac{\text { D. L. Porter for h.C.Wattes }}{\text { Division I Project }}$ Date: $3.11 \cdot 94$ 


\begin{tabular}{|c|c|c|}
\hline & \multirow{2}{*}{$\begin{array}{l}\text { A R GON NE NATIONAL LABORATORY } \\
\text { NOTIFICATION OF SPECIFICATIONS REVISION }\end{array}$} & $\begin{array}{l}\text { Document No. } \\
\text { W0630-0046-BS-01 }\end{array}$ \\
\hline & & \\
\hline & $\begin{array}{l}\text { Title Technical Specifications for X-ray Fluorescence } \\
\text { Spectrometer. }\end{array}$ & Page 1 of 1 \\
\hline
\end{tabular}

-The document number as it appears on this page only shall be used to identify this document. The last two digits denote the revision number of this document (see Revision Authorization block below).

This document is fully representative of the Document No. only when the revision number on its pages correspond with those in the index below.

(INDEX)

INDEX OF PAGE REVISIONS

\begin{tabular}{|l|c|c|c|c|c|c|c|c|c|c|c|c|c|c|c|}
\hline PAGE NO. & 1 & 2 & 3 & 4 & 5 & 6 & 7 & & & & & & & & \\
\hline REV.NO. & 01 & 01 & 01 & 01 & 01 & 01 & 01 & & & & & & & & \\
\hline
\end{tabular}

PAGE NO.

REV.NO.

\begin{tabular}{|l|l|l|l|l|l|l|l|l|l|l|l|l|l|l|l|}
\hline PAGE NO. & & & & & & & & & & & & & & & \\
\hline REV.NO. & & & & & & & & & & & & & & & \\
\hline
\end{tabular}

\begin{tabular}{|l|l|l|l|l|l|l|l|l|l|l|l|l|l|l|l|}
\hline PAGE NO. & & & & & & & & & & & & & & & \\
\hline REV. NO. & & & & & & & & & & & & & & & \\
\hline
\end{tabular}

\begin{tabular}{|l|l|l|l|l|l|l|l|l|l|l|l|l|l|l|}
\hline PAGE NO. & & & & & & & & & & & & & & \\
\hline REV.NO. & & & & & & & & & & & & & & \\
\hline \\
\hline PAGE NO.
\end{tabular}

\section{REVISION AUTHORIZATION}

\begin{tabular}{|c|c|c|c|c|c|c|c|c|c|}
\hline $\begin{array}{c}\text { REVISION } \\
\text { NUMBER }\end{array}$ & 00 & 01 & 02 & 03 & 04 & 05 & 06 & 07 & 08 \\
\hline $\begin{array}{c}\text { DCN } \\
\text { NUMBER }\end{array}$ & - & 007 & & & & & & & \\
\hline $\begin{array}{c}\text { DATE } \\
\begin{array}{c}\text { APPROVED } \\
\text { BY }\end{array}\end{array}$ & & & & & & & & & \\
\hline
\end{tabular}




\begin{tabular}{|c|c|c|c|c|}
\hline & ARGO INE NATIONAL LABORATORY & \multicolumn{3}{|c|}{ W0630-0046-BS } \\
\hline & Tyttlei & Rer. & Approved & 3 Pate \\
\hline & & Page & $-\operatorname{or} \frac{7}{2}$ & \\
\hline
\end{tabular}

\subsection{Scope of Work}

1.1 Contractor shall fabricate, test before shipment, package, deliver, install and retest at the purchasers location, Argonne National Laboratory - West (ANL-W), a energy dispersive $x$-ray (EDX) fluorescence spectrometer or a wavelength dispersive $x$-ray (WDX) fluorescence polychromator equipped with a variable channel monochromator. The instrument provided will be modified by $A N L-W$ for installation in a alpha glove box for field application. The instrument must be capable of handling both solid and solution samples.

1.2 Bidders can submit bids for demonstration models provided: a. The instrument meets the requirements stated in sections 1.0 through section 6.0 .

b. Prior to awarding the contract the instrument is inspected by an ANL-W Technical Representative for approval.

1.3 Bidders shall submit, with their bid, detailed specifications for components which demonstrate that the instrument meets the requirements under Technical Requirements, section 3.0. There shall be no exceptions.

1.4 Contractor shall submit operating, maintenance, electronic diagrams as per section 4.2 .

1.5 Contractor shall train ANL-W personnel as per section 5.4 titled training.

2.0 Applicable Documents

2.1 Electrical Codes

2.1.1 NFPA 70 P-84

2.1.2 FCC Regulation

2.2 Qther

2.2.1 OSHA Regulations, 29 CFR 1910

3.0 Technical Reouirements

3.1 General System Recuirements

For either an EDX or WDX system the following "

requirements apply:

\subsubsection{Overall System Desion and Function}

3.1.1.1 Source Requirements:

The excitation source shall utilize an $x$-ray tube operated system, specifically a Rhodium target. The source shall be in an inverted 


\begin{tabular}{|l|l|l|l|}
\hline & A R G O N N E N A T I O N A I I A B O R A T O R Y & \multicolumn{3}{|c|}{ W0630-0046-BS } \\
\cline { 2 - 4 } & Tectleci Specifications for an X-ray Fluorescence Spectrometer & Rev. & Approved \\
\hline
\end{tabular}

geometry, illuminating the sample from below and thus, capable of analyzing liquid samples. The $x$-ray tube shall provide for a closed loop recirculating flow of coolant to maintain a constant target temperature. The $x$-ray tube output flux shall not exceed $0.25 \%$ RSD ( 1 sigma) over an 8 hour period of continuous operation. 3.1.1.2 Power Generator Supply:

The instrument will operate at $110 \mathrm{~V} 60 \mathrm{~Hz}$. The power generator supply must be capable of operating up to or exceeding 200 Watts. 3.1.1.3 Vacuum Operation/Purge Option: The spectrometer shall provide for vacuum operation as well as an inert gas purge. The system shall have a vacuum pump with gate valve, and pressure gauge.

3.1.1.4 Detector Cooling Requirements:

The $x$-ray detection system(s) shall not use liquid nitrogen cooling. Closed loop cooling or thermoelectrically cooled detectors are acceptable.

3.1.1.5 Quality Assurance and Performance Tests The contractor must demonstrate and show proof that the system meets or exceeds the Technical Specifications at the Purchasers location as per sections 4.0 and 6.0 .

3.1.1.6 Environmental Operating Conditions: The spectrometer will be utilized in an environment which is not climate controlled. The temperature may range from $15^{\circ} \mathrm{C}$ to $35^{\circ} \mathrm{C}$. As such, the spectrometer must be thermally stabilized to $\pm 1^{\circ} \mathrm{C}$ at a temperature selected by the manufacturer. The instrument shall operate within the specified technical requirements in a unregulated environment. 3.1.1.7 Delivery Date: The spectrometer must be delivered and installed by April 10, 1994. 3.1.1.8 Warranty: The instrument will be modified by the Purchaser for operation in a alpha glove box. The instrument must be warrantied for 1 .year from the date of acceptance - see section 5.2. The Detector and Source units will not be . removed from the instrument and shall be fully warrantied. Parts modified by ANL-W will not be covered under the warranty. 


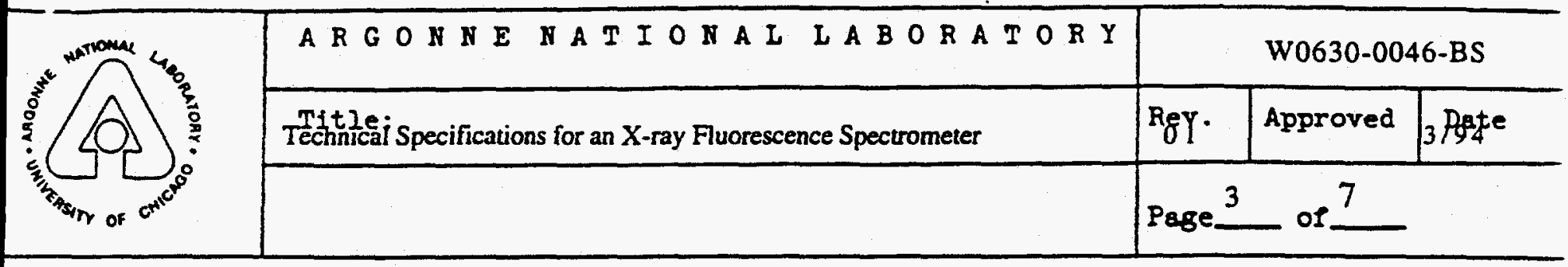

\subsubsection{Major Component Survey}

The XRF spectrometer shall consist of the following:

a. The instrument will be composed of a single main cabinet containing the source, all power supplies, analyzers, detectors, temperature control equipment and vacuum equipment.

b. A personal computer (pc) for control of the spectrometer, data collection and manipulation will be separated from the main spectrometer unit by a minimum distance of 10 feet.

c. The system must be a simultaneous spectrometer system using either an energy dispersive spectrometer or a wavelength dispersive spectrometer as detailed in part d of section 3.1.2.

d. If the XRF spectrometer is a WDX spectrometer the following must apply: It must have a variable channel analyzer. The variable channel analyzer must be able to provide a wavelength scan with a resolution (FWHM) of $150 \mathrm{eV}$ at $5.9 \mathrm{keV}$ and $14 \mathrm{keV}$ respectively. The spectral scan must be stored as an ASCII file in $X Y$ format were $X$ is in units of energy and $Y$ is in units of counts. The spectrometer must detect simultaneously at least the following eight elements: $\mathrm{Si}, \mathrm{Al}, \mathrm{Fe}, \mathrm{Ni}, \mathrm{Cr}, \mathrm{Pb}$, $\mathrm{Cd}, \mathrm{Ce}$. Analyzers and detectors for $U, \mathrm{~Np}, \mathrm{Th}$ and $\mathrm{Pu}$ must be presently available at the time of delivery of the system. These analyzers may be purchased at a later date.

\subsubsection{Individual comoonent Survey}

3.1.3.1 Energy Dispersive Spectrometer

3.1.3.1.1 Resolution:

Energy dispersive spectrometers shall provide an energy resolution of $165 \mathrm{eV}$ or better at 5.9 $\mathrm{keV}$ and $300 \mathrm{eV}$ at $14 \mathrm{keV}$.

3.1.3.1.2 Secondary Source Target Capability Energy dispersive spectrometers shall provide for secondary excitation targets, namely: $\mathrm{Ge}$, $\mathrm{Gd}, \mathrm{Ag}, \mathrm{Zr}, \mathrm{Fe}$ and $\mathrm{Ti}$.

3.1.3.2 Wavelength Dispersive Spectrometer 3.1.3.2.1 spectrometer Requirements: a. The spectrometer must have at least eight monochromators dedicated to the following elements: $\mathrm{Si}, \mathrm{Al}, \mathrm{Fe}, \mathrm{Ni}, \mathrm{Cd}, \mathrm{Pb}, \mathrm{Cr}$ and $\mathrm{Ce}$. Additional analyzers must be able to be added - 


\begin{tabular}{|c|c|c|c|c|}
\hline & ARGON NE NATIONAL LABORATORY & \multicolumn{3}{|c|}{ W0630-0046-BS } \\
\hline & Techitleai Specifications for an X-ray Fluorescence Spectrometer & ReY. & Approved & 3Pfte \\
\hline & & \multicolumn{3}{|c|}{ Page 4 or 7} \\
\hline
\end{tabular}

to at least a total of fifteen elements or be interchanged. If the elements are interchanged the analyzers must be modular and not require technical support from the contractor.

b. A variable channel analyzer shall be provided which is capable of performing energy scans and integrating at a fixed energy. 3.1.3.2.2 Resolution:

a. Each elemental analyzer will have a energy bandwidth of $150 \mathrm{eV}$.

b. The variable channel analyzer must be able to provide a wavelength scan with a resolution (FWHM) of $50 \mathrm{eV}$, be equipped with a LiF (220 or 200) crystal with fine collimators and meet resolution tests which are detailed in Section 4.1.2.

\subsection{Functional and Performance Tests}

4.1 Performance and Test Reouirements

Performance tests will be demonstrated prior to shipping and upon installation at ANL-W.

4.1.1 General: The instrument shall be $100 \%$ operational with all associated hardware and software in place at the time of installation at ANL-W. 4.1.2 Resolution:

a. EDX Spectrometer: The resolution requirements stated in section 3.1.3.1.1 will be demonstrated using a standard containing Mn $\left(K \alpha_{1}=5.89875 \mathrm{keV}\right)$ and $\mathrm{Gd}\left(L \alpha_{1}=6.0572\right)$. In addition, the Thorium $L \alpha_{1}$ and Selenium $K B_{2}$ lines at $12.9687 \mathrm{keV}$ and $12.6522 \mathrm{keV}$ must be baseline resolved (Energy separation $=317 \mathrm{eV}$ ). b. The resolution of the wDX variable channel will demonstrated by obtaining a spectral scan using a standard containing $\mathrm{Mn}\left(\mathrm{K} \alpha_{1}=5.89875\right.$ $\mathrm{keV})$ and $G d\left(L \alpha_{1}=6.0572\right)$ and showing baseline separation of the two respective lines.

Furthermore, it must be demonstrated that the $U$ $L \alpha_{1}$ and $L \alpha_{2}$ lines at $13.6147 \mathrm{keV}$ and 13.4388 $\mathrm{keV}$ can be resolved.

c. The energy of the monochromators for $S i$, $\mathrm{Al}, \mathrm{Fe}, \mathrm{Cd}, \mathrm{Pb}, \mathrm{Ni}, \mathrm{Cr}$ and $\mathrm{Ce}$ are shown in Table 1 . follows :

Resolution tests will be conducted as

a. Standards will be prepared with the each 


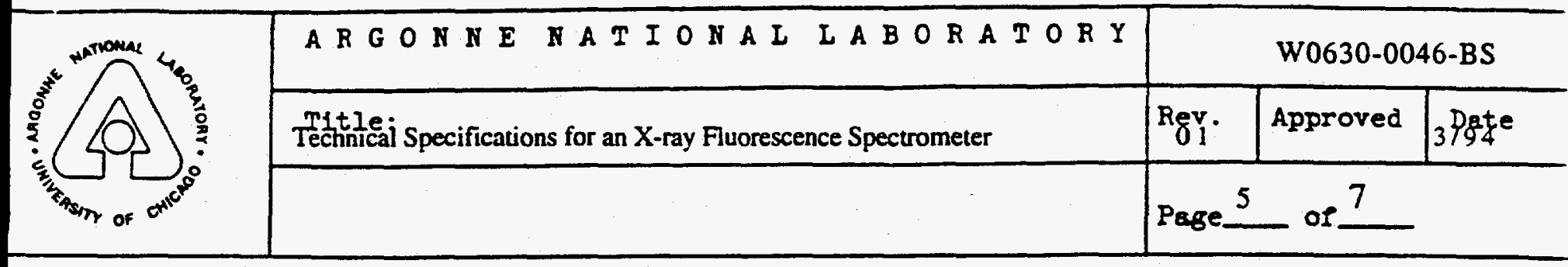

element to be determined with and without the presence of an interfering element. If one assumes a gaussian peak shape then the FWHM equals $2.354(\mathrm{~s})$. It follows that the width of the peak at the base $w_{b}$ (equal to $4 \mathrm{~s}$ ) is equal to 1.699 times the FWHM. Therefor, in order to demonstrate baseline resolution a peak of equal intensity and FWHM located $85 \mathrm{eV}$ from the line of interest shall not contribute to signal by more than $1 \%$ provided that there exists no other interfering emission lines. If no other element has a sensitive emission line at approximately $100 \mathrm{eV}$ from the line of interest then the closest reasonable line will be selected by the Purchaser. Table 1 shows the list of analytes, their energy (kev), interfering element, energy of interfering element (kev) and separation between the two selected lines (in eV).

\begin{tabular}{|c|c|c|c|c|c|}
\hline Element & Notation & Eneroy & Interferent & Eneray & $\mathrm{eV}$ \\
\hline $\mathrm{cd}$ & $L \alpha_{1} / L \alpha_{2}$ & $3.13373 / 3.12691$ & $\mathrm{Ag}$ & 2.98431 & (149) \\
\hline $\mathrm{Cr}$ & $\mathrm{K} \alpha_{1} / \mathrm{K} \alpha_{2}$ & $5.41472 / 5.40551$ & $\mathrm{Ce} \mathrm{LB}_{3}$ & 5.3651 & $(40)$ \\
\hline $\mathrm{Ni}$ & $k \alpha_{1} / K \alpha_{2}$ & $7.47815 / 7.46089$ & $\mathrm{Yb} L \alpha_{1}$ & $\begin{array}{c}7.415 \\
7.5802\end{array}$ & $\begin{array}{l}(45) \\
(102)\end{array}$ \\
\hline $\mathrm{Pb}$ & $I \alpha_{2}$ & 10.4495 & As $K \alpha_{2}$ & 10.508 & $(58)$ \\
\hline $\mathrm{Ce}$ & $L \alpha_{1} / L \alpha_{2}$ & $4.8402 / 4.8230$ & $\mathrm{Ti} \mathrm{KB}_{1,2}$ & 4.93181 & $(96)$ \\
\hline $\mathrm{Fe}$ & $\mathrm{K} \alpha_{1} / \mathrm{K} \alpha_{2}$ & $6.40384 / 6.3908$ & $\begin{array}{ll}\text { Dy } & \mathrm{L} \alpha_{2} \\
\mathrm{Mn} & \mathrm{KB}\end{array}$ & $\begin{array}{c}6.4577 \\
6.49045\end{array}$ & $\begin{array}{l}(54) \\
(86)\end{array}$ \\
\hline
\end{tabular}

Table 1

4.1.3 Calibration and Limits of Detection: NIST glass standards $610,612,614$ and 616 will be supplied by the Purchaser. The instrument shall obtain calibration plots for $\mathrm{Fe}, \mathrm{Ni}, \mathrm{Pb}$, $U$ and Th. The instrument will have LODs for $U$ and $\mathrm{Th}$ below $10 \mathrm{ppm}$ in the glass. The instrument will demonstrate the limits of detection from the measurement of $3 \mathrm{~mm}$ thick NIST glass standards containing $U$ and $T h$ at 38 ppm levels and a certified glass standard (a "blank") with $U$ and $T h$ levels < $0.1 \mathrm{ppm}$. 


\begin{tabular}{|c|c|c|c|c|}
\hline & ARGONNE NATIONAL IABORATORY & \multicolumn{3}{|c|}{ W0630-0046-BS } \\
\hline & Tectle ${ }_{\text {Tea Specifications for an X-ray Fluorescence Spectrometer }}$ & Rev. & Approved & ${ }_{3}$ Pate \\
\hline & & \multicolumn{3}{|c|}{ Page 6 of 7} \\
\hline
\end{tabular}

4.1.4 Stability: the spectrometer and source shall measure a $S i$ standard over a 32 times over an 8 hour period (every 15 minutes) at a power of $50 \mathrm{keV}$ and $4 \mathrm{~mA}$. A control chart will be generated which shows a $95 \%$ confidence level a drift no greater than $0.5 \%$ throughout the test period.

4.1.5 Shielding: The instrument will have a total radiation leakage of $<0.25 \mathrm{mR} / \mathrm{h}$.

4.1.6 Data Handling and Instrument Control. The instrument will have: a) computer control of source voltage and current, detector gain and integration time.

b) Provide instrument temperature readout.

c) Provide for automated calibration, scattering background correction, sample analysis and reporting.

d) Statistical control programs to generate Qsum and control charts must be included.

e) The instrument will have an RS-232 port for interfacing to other instruments and data transfer.

\subsubsection{In-plant Test Results:}

The instrument will meet all criteria as stated in section 2.0 through 6.0 at the Manufacturers site. Each set of criteria will be documented.

\subsubsection{Final Acceptance:}

The instrument will be installed at ANL-W and retested to demonstrate that all criteria stated in sections 2.0 through 6.0 are met. $50 \%$ of the payment of the instrument will be withheld until all criteria have been met. Warranty shall not begin until the instrument has been fully accepted under the above conditions.

\subsection{Vendor support.}

5.1 Installation: The manufacturer will ship, unpack and install the instrument at ANL-W.

5.2 Warranty:

The instrument will be warrantied as described in section 3.1.1.8 from the date of acceptance. 5.3 Service: While under warranty, the Vendor will repair any defect or operational problem at their 


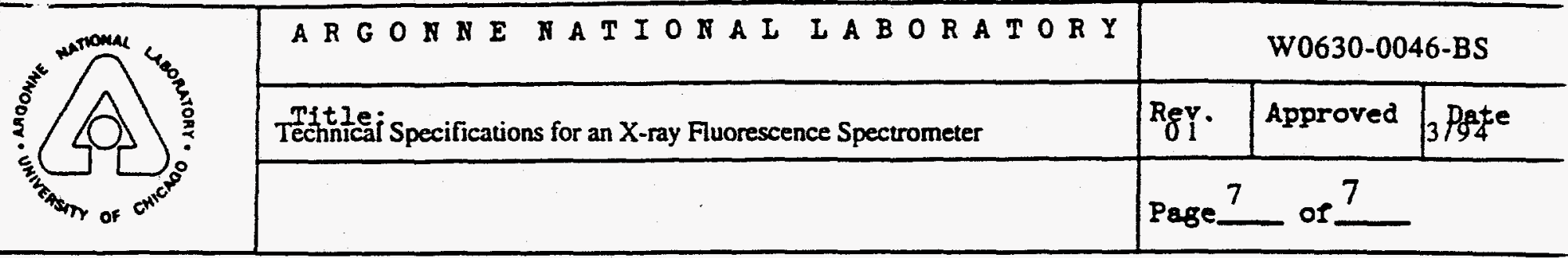

cost within a two week period of notification from ANL-W.

5.4 Training: Two operators will be trained in the complete operation of the instruments hardware and software at the ANL-W site upon installation of the instrument.

\subsection{Packaging and Delivery.}

6.1 Packaging: The vendor will pack the instrument and insure its safe arrival at $A N L-W$ for

installation by the date set in section 3.1.1.7.

\subsection{Shipping Destination:}

Ship to : Argonne National Laboratory

INEL, EBR II Site

Bldg 781, Receiving Warehouse

Scoville, Idaho 83415

6.3 Notification: An ANL-W technical representative will be notified 1 week prior to shipping of the instrument. Delays in shipping will be immediately reported. 